\title{
LE SOMMEIL D'UN MANNEQUIN: \\ Exploring Material Memory through Film
}

by

\author{
Laura Del Giacco \\ B.F.A., Concordia University, 2013 \\ A Major Research Project \\ presented to Ryerson University
}

in partial fulfillment of the

Requirements for the degree of

Masters of Arts

in the Program of

Fashion Studies

Toronto, Ontario, Canada, 2016

(C) Laura Del Giacco 2016 


\section{AUTHOR'S DECLARATION}

\section{AUTHOR'S DECLARATION FOR ELECTRONIC SUBMISSION OF A MAJOR RESEARCH PROJECT (MRP)}

I hereby declare that I am the sole author of this MRP. This is a true copy of the MRP, including any required final revisions, as accepted by my examiners.

I authorize Ryerson University to lend this MRP to other institutions or individuals for the purpose of scholarly research.

I further authorize Ryerson University to reproduce this MRP by photocopying or by other means, in total or in part, at the request of other institutions or individuals for the purpose of scholarly research.

I understand that my MRP may be made electronically available to the public. 


\begin{abstract}
Le Sommeil d'un mannequin is a practice-based research project that examines the relationship between the female body and the body of the mannequin through creative methods of plaster body casting and experimental film. The film, Le Sommeil d'un mannequin, conveys the psychic experience of memory found in the unconsciousness state. Through the use of experimental filmmaking, this project speaks to the transformative power of memories and the interpretation of memory that is implied in the psychoanalytic writings of Sigmund Freud.
\end{abstract}

Subsequently, this project bares importance to the study of material culture because it takes into account the human essence present in the fabrication and production of cultural objects. Applying Jules Prown's method of object analysis uncovered the role of the mannequin to be more than just a cultural display of feminine identity. 


\section{ACKNOWLEDGEMENTS}

In presenting this major research paper, I would like to thank Professor Joseph Medaglia for convincing me to continue on the path of a creative project as well as for helping me see the success of using film for academic discoveries. Without him, the realization of this project would not have been possible.

I would also like to thank my sister, Marianna Del Giacco, for patiently standing still while I covered her body in plaster bandages, but more importantly for participating in this creative journey with me. In addition, I would like to thank the talented musician, Dan Kiely, for producing the music, as well as for some written words that Sofia Del Giacco kindly volunteered to narrate.

The success of Le Sommeil d'un mannequin would not have been possible without the help of Professor Joseph Medaglia, Marianna Del Giacco, Dan Kiely, and Sofia Del Giacco. 


\section{TABLE OF CONTENTS}

Title Page

i.

Author's Declaration

ii.

Abstract

iii.

Acknowledgements

iv.

Table of Contents

V.

List of Illustrations

vii.

Introduction

Chapter 1: Literature Review

1.1 Mannequins: Towards The Seduction of the Female Body

1.2 Towards an Investment of Surrealism and the Female Body

1.3 Beyond Male Surrealists

1.4 Body Works

1.5 The Use of the Female Body in Film

1.6 Towards a Counter Cinema

Chapter 2: Methodology

2.1 Casting Memories

2.2 The Study of Material Culture: A Guide to Object Analysis

\subsection{Description}

\subsection{Deduction}

2.5 Speculation

2.6 Practice-led Research: Towards the Production of Knowledge in "Artistic Research" 
Chapter 3: Theoretical Framework

3.1 Screen Memories According to Freud: Towards a Psychoanalytic Perspective 3.2 The Theory of Abjection

3.2 Alternatives to Psychoanalysis: Benjamin, Baudrillard, The Art of Mechanical Reproduction and The Simulation of Reality Found in Film

Chapter 4: Analysis, Results, Discussion

4.1 Synopsis

4.2 Analyzing the Narrative and Film Technique in Le Sommeil d'un mannequin

4.2 The Abjection of the Uncanny: From Object to Abject

4.4 The Result of Using Film \& Memory Within Surrealist Practice

4.5 A Discussion of Prown, Freud, Benjamin, and Baudrillard

Conclusion

Appendix

vii.

Work Cited

viii. 


\section{LIST OF ILLUSTRATIONS}

Figure 1. Hans Bellmer, Plate from la Poupée, 1936.Gelatin Silver Print. Museum of Modern Art, New York.

Figure 2. Hans Bellmer, Plate from la Poupée, 1936.Gelatin Silver Print. Museum of Modern Art, New York.

Figure 3. Hans Bellmer, Plate from la Poupée, 1936.Gelatin Silver Print. Museum of Modern Art, New York.

Figure 4. Hans Bellmer, Plate from la Poupée, 1936.Gelatin Silver Print. Museum of Modern Art, New York.

Figure 5. Judy Chigo. The Dinner Party (Virginia Woolf Place Setting).1974-79. Mixed media: ceramic, porcelain, textile. Brooklyn Museum, New York.

Figure 7. Le Sommeil d'un mannequin. Dir. Laura Del Giacco. Perf. Marianna Del Giacco. 2016. Film

Figure 8. Le Sommeil d'un mannequin. Dir. Laura Del Giacco. Perf. Marianna Del Giacco. 2016. Film

Figure 9. Le Sommeil d'un mannequin. Dir. Laura Del Giacco. Perf. Marianna Del Giacco. 2016. Film

Figure 10. Le Sommeil d'un mannequin. Dir. Laura Del Giacco. Perf. Marianna Del Giacco. 2016. Film

Figure 11. Le Sommeil d'un mannequin. Dir. Laura Del Giacco. Perf. Marianna Del Giacco. 2016. Film

Figure 12. Le Sommeil d'un mannequin. Dir. Laura Del Giacco. Perf. Marianna Del Giacco. 2016. Film

Figure 13. Le Sommeil d'un mannequin. Dir. Laura Del Giacco. Perf. Marianna Del Giacco. 2016. Film 


\section{Introduction}

Seduced by the enchanted and autonomous body of the mannequin, I began this research project with one simple question in mind: "What is the relationship between the mannequin and the female body?" Putting aside all preconceived notions of the mannequin's historical and social patterns (i.e. modernity, femininity, and consumption), this research seeks to provoke a new conversation between the mannequin and the female body by way of bringing forth the female unconscious state within the inanimate body of the mannequin. In order to elucidate the relationship between female essence within the body of the mannequin, I created a mannequin torso molded after the body of my sister, Marianna Del Giacco (who I will refer to as "the female participant" and or "female protagonist" throughout this paper). The casted mannequin and the female participant were then used in an experimental film to explore notions about memories found within material objects. Le Sommeil d'un mannequin fits within the style of surrealism and incorporates the superimposition of black and white images, along with the video's ambient soundtrack and voice-narration, to illustrate memories found in the state of unconsciousness.

I video recorded the mannequin and the female participant in a staged reenactment of the casting process and later manipulated the recorded footage to resemble past memories that the female participant and I had experienced. In my first attempt, the experimental clips that I made were unconsciously centered on psychoanalytic concepts of the self, of identification, and of desire. However after finalizing and analyzing my film, the frame of this research shifted to the direction of screen memories, relating to studies found 
within psychoanalysis. Since my speculations were based solely on observations, in order to fully conceptualize and theorize Le Sommeil d'un mannequin within the parameters of academic research, I used psychoanalytic theory as the primary theoretical framework for this study, along with the writings of Walter Benjamin and Jean Baudrillard. In my effort to convey concepts of memory through the lens of psychoanalysis, Le Sommeil d'un mannequin echoes the simulation of a human entity and emulates the anxieties and fears found in the memories of the unconscious mind.

The realities of memories are called into question as the depiction of memories on screen draw relations to the mechanism of using film. By way of using a camera to suggest visual analogies of "memories" this research project consequently draws attention to the artifice of using film to document reality. This research questions the complex relationship between the cinematic apparatus and the dimensions of memory, and seeks to employ the interpretation of memory as evidence of 'truth.' By contrast, the use of film alludes to actuality whereby the activities that take place in Le Sommeil d'un mannequin are depictions of actual recalled memories.

Le Sommeil d'un mannequin is created on the premise that memories cofounded in objects, even objects with unintended cultural inscription like the body of a mannequin, can enable truth and strengthen dimensions of memory. Applying Jules Prown's method of object analysis to this project uncovers the role of the mannequin to be more than just a cultural display of feminine identity. No longer standing as an inanimate cultural object behind glass, the mannequin in Le Sommeil d'un mannequin materializes into a visual analogy of memory by way of mirroring and simulating human entity. 


\section{Chapter 1 \\ Literature Review}

This literature review examines topics related to the relationship between the female body and the mannequin from the 1960's to present day. The mannequin's erotic dimensions are traced from the start of the mannequin's body appearing on public display. In addition, this section examines literature that speaks to the 'feminized bodies' within surrealist art, body art, and filmmaking practices in an attempt to reconceptualize feminine subjectivity in experimental film and visual art.

\subsection{Mannequins: Towards the Seduction of the Female Body}

By the 1960's, advertising agencies discovered that mannequins with "real" people faces could sell products that consumers would be able to identify with (Schneider 13). As the mannequin embodied promotions of both objects and subjects to be consumed, the image of the female mannequin became quickly tangled in the consumption of women and products alike. Patrizia Calefato claims that a mannequin's body no longer signified garments alone but rather a whole other world: "Mannequins are the new divas, distant stars behind glass, constructed to fit a public space where their visibility is made known to everyone" (Calefato 55). The body of the mannequin thus became a sign exchange in the worldly image of fashion.

According to Gonberg, the concept of actively influencing the consumer was explicitly defined in terms of a seduction via the female body. A 1922 book on advertising that Gonberg cites, Beware Beautiful Women, presents the following observation: 
"The lover [...] transfers the feelings by the body of his mistress to her clothes, her furniture, her home. Just so can the poster influence the public in favour of the commodity and of the brand name" (qtd. in Gonberg 381).

The illustration of this transfer of desire from 'mistress' to object, Gonberg explains, represents the commodity in juxtaposition to a female figure. As such problems began to arise and questions about how to stop women's bodies, instead of the object, from stealing the show, became of great concern to advertising companies. Les Affaires et l'affiche concluded that "it is necessary that all attention be concentrated on the object, on the commodity advertised in such a way as to endow it with a vibrant intensity [une vive intensité]" (qtd. in Gonberg 382). The point was not to eliminate the female body but rather to insist upon and enumerate devices whereby the 'distracting' quality of the female body might be transferred to the object of sale instead (Gonberg 382). The only way to juxtapose female body and commodity for profit was through the mannequin, a perfect simulacrum of the female body. As such, mannequins qualified as effective advertising in that they were able to divert from themselves to a commodity.

However, as a result of looking at an object displayed on a mannequin, the mannequin had transformed into a camouflage of the inner psyche. Gonberg writes:

"[...] discourse in the mannequin concerned the male gaze as much as the woman consumer's look. The idea of a male lover's preoccupation with his mistress' object, the injunction to be suspicious of lovely women, as well as the recurring references to a repulsion produced by a too-close facsimile of the female body, all suggests the dynamics of fetishism"

Alison David-Mathews further states in her essay, "Body Doubles: The Origins of the Fashion Mannequin”, “[...] enchanted consumer's projected erotic fantasies onto them [...]" (1). Consequently, the representation of the female form that was replicated on the 
mannequin evoked fetishistic practices about the object of violence, and subsequently became the focus in surrealist art.

\subsection{Towards an Investment of Surrealism and the Female Body}

Surrealism originated in the trenches of the First World War, when Andre Breton, among others, became exposed to the human psyche, as methods of psychoanalysis were introduced. In Surrealism and the Exotic, Louise Tythacott writes:

"From these experiences, not only did an ardent ant-war spirit emerge, but the oneiric disorientation witnessed by Breton became a leitmotif of the subsequent surrealist movement. Surrealism, and its anarchic predecessor Dada, defined themselves in radical opposition to the brutalized societies all around them-and their rejection of values of European life drew them ineluctably toward non-European beliefs" (Tythacott 1).

Surrealists found many ways to provoke the "irruption of otherness" (Tythacott 2). They collected, categorized, displayed, and juxtaposed strange and incongruous artifacts. In his Second Manifesto (in 1929), Breton defined Surrealism in terms of the resolution of opposites, as the search for the point at which "life and death, the real and the imagines, the past and the future, the communicable and the incommunicable, the heights and the depths, ceased to be perceives as contradictory" (Breton 76-7). Tythacott writes that Surrealism sought to destroy artificial contradictions created by modern rationalism because they believed that industrialization, and its warlike consequences, had alienated human kind from "real" experience of the world. Moreover, Tythacott writes "They sought to dissolve antagonism between reason and desire, conscious and unconscious, mind and body, work and leisure, and in art they derided the arbitrary bourgeois opposition of function and aesthetics" (19). 
In Silent Partners: Artist and Mannequins from Function to Fetish, Jane Munro examines the mannequin in its varied guises, from wax to wood, under the context of $19^{\text {th }}$ century art practices. She argues that over the course of the 1800's, the mannequin gradually began to emerge in increasingly complicated ways, playing on the unnerving psychological presence of the human figure. Munro elaborates on how partnerships between artists and mannequins changed with cultural shifts over time, particularly during a time when new ideas about what it meant to be human arose. Artists began depicting mannequins in studio scenes to elicit psychological responses (Munro 282). The result was suggestive, erotic, and sometimes troubling.

In their exploration of the human unconscious, in spite of their lifelike appearance, Surrealists exploited the uncanny inertness of mannequins with notions of sexual relations. Within surrealist practice, the mannequin was often used to evoke implied sexual 'frisson' between real and artificial figures. In "What Does a Man Want? Reflections on Surrealism Desire Unbound, Danielle Knafo notes that the solution to male gender anxiety often takes the form of viewing the female body as a fetishistic object or as a sadistic drive. It is because of surrealism's concept of the object that the mannequin becomes subject to brutal violations of the female body. In "Man Ray's Disarming Venuses: Deconstructing the Classical Torso in Surrealist Photography" Kristen A. Hoving examines the work of Man Ray and illustrates the way in which he has used the female torso to depict a grotesque appropriation of the uncanny human form. In the context of modern art, mannequin manufacture Siégel, depicted a faceless and disconcerting representation of mannequins staring blankly ahead in their, found in their brochures (Gonberg 388). In surrealism, the facelessness represents more than just 
silence; "the wiping out of facial features (one of the most important means of expressions and signs of identity) emphasized the mannequin as an object of telling indication of male anxiety" (388).

Hans Bellmer's photographs of distorted and deformed dolls are quintessential examples of the preceding surrealist misogyny of male anxiety (Figures 1.-4.). Bellmer's Poupée (1935), a series of doll-like mannequins, violently eroticizes the female body into fragmented pieces. In viewing Bellmer's work, in the context of surrealism, we are able to see the distorted bodies as a form of displacement of male anxiety onto the replicated bodies of women. In "Anxiety and The Pervasion of Post War Paris," Amy Lyford argues that 'Bellmer's work, and the work of other male surrealists who depicted fragmented female bodies, might reflect not only misogyny but also the disavowal of emasculation through symbolic transference" (15).

The fabrication of misogyny and masculinity that is inherent through "symbolic transference" presents this literature review with a point of departure and moves towards the reconceptualization of viewing the female body within a different context. Instead of inducing the "phallic" conversation that is often (although not always) present within psychoanalytic explorations of the female body, this research instead speaks to viewing the female body as capable of resonating with ideas other than that of phallic anxiety.

\subsection{Beyond Male Surrealists}

Today, Surrealism as a conceptual art practice can arguably be defined by the legacy of male artists like Salvador Dalí, Réne Margaritte, and Andre Breton: names that have 
become famously recognized within the surrealist movement. However, while these artists are often considered synonymous with surrealism, in Siel Ju's dissertation, "Simulations/Shape Shifting Surrealism: Rikki Ducornet's Poetry of Feminist Intersubjectivity," new evidence is brought forth that favours contemporary surrealist work, especially that which pertains to female artists.

Through the exploration of contemporary female surrealists, Ju traces the constructive elements and aesthetics that have contributed to the recognition of those female artists' work. According to Ju's research, "the disdain for authority and desire for invention of their male peers as a starting point, contemporary female surrealist extend and transform the ideas and techniques of their male cohorts to upset divisions such as dream and reality, self and other, and finally, male and female-in the sometimes violent assertion of an active subjectivity" (59). In examining the work of Rikki Ducornet, Ju uncovers new feminist vocabulary and iconography for contemporary surrealism, employing surrealism as a tool towards feminist ends. Ju argues that "Ducornet's poetry reclaims surrealist techniques to posit a female desire and artistic agency that emphasizes a fluid intersubjectivity" (59).

Ironically, for a movement that so violently distorted female bodies, surrealism has managed to capture the attention of so many contemporary female artists. Thus, the question begs: Why are there so many contemporary female artists involved in the surrealist movement? Once again, Ju claims that the outpouring of surrealist literature reflects in part, a desire to reclaim and champion the work of underrepresented female artists. (60). In Subversive Intent: Gender Politics and the Avant Garde, Susan Suleiman 
examines the works of contemporary female surrealist artists, Hélène Cixous, Marguerite Duras, Monique Wittig, Angela Carter, Jeanette Winterson, Leonora Carrington, Barbara Kruger, Jenny Holzer, Cindy Sherman and others, showing through their practice the parodic critiques of patriarchal ideologies. Therefore, in the remaining literature I will illustrate how women have used their bodies in other artistic movements as an indication of autobiographical art, focusing on the creative act of 'body art' and 'body works' itself, rather the misogynistic portrayal that women's disembodied and erotized bodies have been inexplicably subjected to within the surrealist movement.

\subsection{Body Works}

Lucy Lippard writes in "The Pains and Pleasures of Rebirth: European and American Women's Body Art", that "when women began to use their own faces and bodies in

photoworks, performances, film, and video, rather than being used as props in pieces by men, it was inevitable that body art [in the context of women's art] would acquire a different tone" (121). The definition of body art refers to the artistic movement that occurred in the 1970 's, in which the presence of the artist was regarded to be an integral part of the work (121). Body art, since its involvement with performing art, has raised concerns in regard to issues brought forth by the feminist movement.

Body art by women deals almost exclusively with female imagery and feminist issues. According to Lippard, the concept of "female imagery" arose through the ideas and programs of Judy Chicago and Miriam Schapiro (Lippard 123). The installation by Judy Chicago titled The Dinner Party (Figure 5.), for example, according to Jane F. Gerhard, "is the most monumental work of the 1970's feminist art movement" (11). The Dinner 
Party, is a unique feminist production to which Judy Chicago challenges notions of womanhood via images of the vulva molded on every dinner plate. Yayoi Kusama, Charlotte Moorman, Yvonne Rainer, and Joan Jonas among others are other female artists who are also concerned with concepts of 'female imagery.' Joan Jonas, for example, constantly presents her nude self in public in an attempt to discover it beyond acculturations (Lippard 125). Another case is found in the works of Carolee Schneemann. Although her works have always been concerned with sexual and personal freedom, her intentions are to prove that "the life of the body is more variously expressive than a sex-negative society can admit to" (Lippard 126). According to Lippard, "When women use their bodies in their artwork, they are using their selves; a significant psychological factor to convert these bodies or faces from object to subject" (124). The combination of body art with feminist consciousness thus opens up new possibilities for women artists who want change in their art form.

\subsection{The Use of the Female Body in Film}

In "Visual Pleasure and the Narrative Cinema," Laura Mulvey analyzes the role of the female body in narrative cinema. Mulvely argues that the role of the female body is that of an exhibitionist. Her role is to be looked at and put on display for no other reason than to be objectified as a sexual object. In "Visual Pleasure and Narrative Cinema," Mulvey focuses on narcissism and narcissistic identification, both of which involve the reading of phantasies power, mastery, and control that is derived from the mind of the male spectator when gazing upon the female body (177). 
In "Women's Cinema as Counter- Cinema," Claire Johnston also examines the ways in which the female body has been used in cinema. Drawing on the concept of mythologies from Roland Barthes, Johnston examines the myths governed by cinema and suggests that the function of women in narrative cinema is part of sexist ideologies. Johnston, like Mulvey, argues that the "fetishistic image [of a woman] portrayed relates only to male narcissism: woman represent not herself, but by process of displacement, the male phallus" (121). Johnston and Mulvey's developments are clearly rooted within psychoanalytic theory and aim to identify pleasure viewings specific to cinema. In Mulvey's point of view, feminist cinema was an avant-garde film practice that would work to free the look of the camera into its materiality in time and space and the look of audience into dialectics and passionate detachments (Smelik 494).

\subsection{Towards a Counter-Cinema}

In Feminist Film Theory, Anneke Smelik argues that in order to avoid conventions of classic cinema, one must accommodate a female point of view. Within the parameters of feminist filmmaking, an important theoretical shift occurs, whereby the goal of feminist cinema is aimed at constructing an ideology that rejects conventions of classical cinema. For instance, the female subject must be excluded from the male language found in classical narratives (Smelik 495). In the context of "realism" and documentary genre, Smelik argues that women must manufacture and construct the "truth" about women's experience and not merely reflect it (495).

Sally Potters, for example, considers Smelik, Mulvey, and Johnston's arguments by way of avoiding conventions of classic cinema and producing a female point of view in her 
1979 avant-garde movie Thriller. Potter achieves this by deconstructing the classic melodrama of Giacomo Puccini's 1896 La Bohème (Smelik 493). Potter splits the character Mimi into two personalities, one that is part of the narrative and one that is outside the narrative, in order to investigate and critique on how the female body is unfolded in narrative cinema. On a psychological level, Potter excludes the female protagonist Mimi from any male language and classic narrative. Through visual and acoustic communications, Thriller's soundtrack includes a dominant female voice, as well as repeated laughs, repeated shrieks, and the sound of a beating heart (493). While there are typical components of the classical thriller and horror genres, Thriller does not give rise to any such suspense: "Instead it refocuses the attention of the spectator on the enigmas surrounding the female subject in classical discourses" (493). Other examples of counter-feminist cinema are the works of Chantal Akerman's Jeanne Dielman 23 (1975) and Quai du Commerce (1975), and one from Laura Mulvey and Peter Wollen, Riddle of the Sphinx (1977).

Reinterpreting classic narratives with a more harmonious female point of view has led female filmmakers with the ability to present works that are not inherent within the discussion of masculinity and sexual discourse found in traditional narratives. The diversity of contemporary feminist filmmaking has allowed the success of women's selfrepresentation to be projected on the big silver screen. 


\section{Chapter 3}

\section{Methodology}

The methodology for this project is twofold. First, as this creative research is concerned with producing knowledge through the use of art practice, the methodology for this investigation is based on the curriculum of practice-led research. The premise of using practice-led research for this research not only explores the theoretical basis of artistic practice but also positions it within the discourse of academic research (Sullivan 6). Second, this research crosses paths with the study of material culture as a complimentary methodological approach. Using the study of material culture for this creative research, is done with the intent of extracting 'knowledge' and or 'meaning' from a man-made object.

\subsection{Casting Memories}

Since the objective of my research project was to explore the relationship between the mannequin and the female body, rather than use an already manufactured mannequin for this study, I decided to cast a mannequin out of plaster, molding the body shape after a female participant. The total process for this stage took about four hours, most of which was spent painting silicone liquid on the body and wrapping the female participant in plaster bandages. Once the silicone had hardened and the mannequin had been casted, I decided to examine my mannequin with Jules Prown's method of object analysis. Prown's methods allowed me to uncover new meaning and form new ideas regarding the body of my mannequin. 


\subsection{The Study of Material Culture: A Guide to Object Analysis}

In "The Study of Material Culture Today: Towards and Anthropology of Technical Systems", Pierre Lemonnier writes, "The study of material culture has long been the study of lifeless objects" (147). Prehistorians, Lemonier argues, have been working to try to associate material reconstruction (sometimes experimental, sometimes intellectual) into objects that are under scrutiny. For example, for the ethnologist, this has generated new approaches in fieldwork and new theoretical reflection on material culture. However as a study concerned with the investigation of a cultural object as primary data the information attributed to an object can have an array of definitions, definitions so broad that we must rationalize our understanding within a proper form of method, in order to imagine information in relation to a variation of cultural references.

The method of object analysis proposed in Jules Prown's essay "Mind in Matter: An Introduction to Material Culture Theory and Method," suggests that in order to understand an object in relation to its cultural references (i.e. beliefs, values, and or assumptions), three stages are necessary: description (recording of evidence from the object itself), deduction (interpreting the interaction between the object and perceiver), and speculation (framing the hypotheses and questions which lead out from the object to external evidence for testing and resolution) (Prown 7). As such, Prown's method of object analysis was applied to the preliminary stages of this investigation, and by using Prown's method I uncovered evidence of unconscious subject matter present in the body of my mannequin. 


\subsection{Description}

In the first stage of analysis I began by documenting the mannequin in its original state. I soon realized that the inanimate mannequin, which was heavy in weight, static in movement, and imperfect was aspired by the conviction of my own unconscious bias towards dominant ideologies of beauty found in the fabrication of mass produced mannequins. I had created a mannequin that countered normative versions of beauty and slenderness. "Heavy”, "Imperfect", "Thick", "Busty", "Full-Figured" and "Curvilinear in Shape", are some of the key words that I used to describe my mannequin for this stage. As I read these words out loud, I realized that I had visually encoded my mannequin with my own bias views of beauty. Thus if my mannequin countered normative versions of beauty and slenderness, and was visually encoded during the stage of production with such biased intentions in mind, this begs the question then: "Can my mannequin still be used as evidence for this research"?

Prown writes that external information that is evidence drawn from outside of the object, including information regarding the maker's purpose or intent - plays an essential role in the process of object analysis. Such an approach is therefore inclusive, not exclusive (6). Thus despite the fact that my own bias intentions had been visually represented, the mannequin I created nevertheless could still be used as to further examine the relationship between the mannequin and the female body. Using my mannequin rather than that of an premade display mannequin allowed me to contrast my research against idealized normative imagery of the female body. Therefore, with the intention of my 
mannequin now fully realized, I posed the question once again: "What is the relationship between the mannequin and the female body?"

\subsection{Deduction}

Subsequently, in the stage of deduction I moved to analyze the physical experience, first between the object (i.e. mannequin) and the beholder (i.e. female participant), and then between the perceiver (i.e. researcher). While the premise of this research deals with the memories of female embodiment, the initial realization that occurred between the object of the mannequin and the female participant however, was saturated in feminine idealization. The initial reaction that occurred was that the female participant, after gazing upon her replicated body, yearned for an idealized feminine body. Even though the mannequin was molded after her own body shape, the female participant evoked a sense of fear from the image of herself. It was clear that the visual recognition of herself, alienated the female participant, and tensions between her image, identity, and desire were consequently brought forth. The experience between the participant and the object of her casted body, was suggestive towards Julia Kristeva's finding on the abjection of the self (which I later explore in my final discussion of Le Sommeil d'un mannequin).

The experience that I had shared with the mannequin however, was quite different. While handling the mannequin I was not able to conclude any additional engagement other than the one that resided in my mind. I had casted a mannequin that shared no content other than the content of counter normative ideologies that I had imposed. Unlike the participant I did not share the same reaction when gazing at the result. I soon realized that 
the reaction from the female participant was a result of what was missing between the mannequin and the female participant - an embodied essence of female presence.

Taking this research one step further, since I had documented the making of the mannequin with a camera, I decided to enter into a pictorial space of observation. My subjective reactions to the images on screen pointed towards elements of recollection and the unconscious mind, which as a result moved my research into an 'imaginative' stage of speculation.

\subsection{Speculation}

Prown argues that in the the final stage of speculation, other than exploring the questions of the creative imagining, the perceptions or ideas in this stage should involve theories derived from external evidence, in order to formulate a proper response (11). Given that I had uncovered elements of recollection and the unconscious mind in the former stage of deduction, I brought into consideration the theoretical framework of psychoanalytic studies. Through the lens of psychoanalysis, the elements of recollection and the unconscious mind that I deduced from the images on screen echoed towards the dimension of memory and the anxieties and fears found in the unconscious mind of the female participant. By interpreting the reaction of the female participant against the mannequin, the engagement that developed between the female body and the mannequin was suggestive towards a more complex relationship.

I decided to turn my findings into an experimental film, whereby I used visual analogies that I examined in the stage of deduction and speculation, to further form and answer my 
own research question. Therefore in this final stage of object analysis, I modified my findings with the conviction of practice-led research in mind.

\subsection{Practice-led Research:}

\section{Towards the production of knowledge in "Artistic Research"}

Researchers have been taught to retrieve information in abstract forms, words, and numbers. But in the pursuit of artistic research, visual analogies can also provide us with an alternative form of knowing. The Arts and Humanities Research Board in the United Kingdom advocates the following: "Practice-led research is a distinctive feature of the research activity in the creative and preforming arts. As with other research conducted by arts and humanities researchers, it involves the identification of research questions and problems, but the research methods, contexts, and outputs then involve a significant focus on the creative practice" (Sullivan 47).

Through creativity and practice, this type of research thus aims, "to illuminate or bring about knew knowledge and understanding, and results in outputs that may not be text based, but rather a performance (music, dance, drama) design, film, or exhibition" (qtd. in Sullivan 47). Moreover in Practice-led Research, Research-led Practice in The Creative Arts, Graeme Sullivan writes, "the central strand that binds the four interconnecting areas of practice is inherently theoretical and is the site where research problems and issues are found and explored- this is the 'making space' of the studio experience which is central to theorising practice as research" (Smith Dean 49). 
Since my speculations were based on the methods of Prown's object analysis, in order to fully conceptualize and theorize my experimental film, Le Sommeil d'un mannequin, within the parameters of academic research, I subsequently used psychoanalytic theory as the primary theoretical framework for this study, along with ideas from Walter Benjamin and Jean Baudrillard. The results of using practice led-research can be found in the final section of this paper. The following section will elaborate on the theoretical underpinning that is central for using practice-led research. 


\section{Chapter 3}

\section{Theoretical Framework}

Through the interpretation of psychoanalytic studies, Le Sommeil d'un mannequin employs the concept of memories and reflects the discourse and practice of Freud's writing on "screen memories." Le Sommeil d'un mannequin argues for the concept of screen memories as a way of conceptualizing notions of memory that were recalled during the production of the mannequin. Annette Kuhn writes that memories can be a liberating force that undercuts assumptions about the transparency or the authenticity of what is remembered, treating it not as "truth, but as evidence of a particular story: material for interpretation, to be integrated, mined for its meanings and possibilities" (186). Keeping this in mind, Le Sommeil d'un mannequin uses the theorization of screen memories to argue material interpretation of meanings that is found in the relationship between the body of the mannequin and that of the female body. As a secondary interpretation, underpinning Freud's theory of the unconscious, included in this section is an overview of Julia Kristeva's writing on abjection. More, as a means to bridge film within the context of this research, I have also included the works of Walter Benjamin and Jean Baudrillard.

\subsection{Screen Memories According to Freud: Towards a Psychoanalytic Perspective}

Freud maintains that with "screen memories", "memories from childhood may be incorrectly recalled or recalled in a way that magnifies or minimize their importance, thereby masking another memory of deep emotional significance" (Freeman 2). In other words, screen memories are memories that are subject to substitution. Freud argues that 
certain memories depict isolated fragments of childhood experience (Lafarge 1250). These memories, according to Freud, had the quality of clarity and sharpness, but were held with a sense of conviction, and where nonsensical as they could only be remembered indirectly, inedited and in a distorted form (1250). However, the problem with Freud's argument is that "in the past screen memories have been viewed and employed rather-one dimensionally as a memory that obscures" ( Freeman, Melamed and Nienass 1), leaving no room to produce or generate knowledge about the past.

Through the writings of Phyllis Greenarce, this research moves away from using screen memories as something that simply obscures; rather, theory about screen memory is used as an informative practice for the production of knowledge. The findings of Phyllis Greenarce, who contributed to the study of screen memories after Freud abandoned the theory, looks at screen memories as an act of remembering, sharing equal importance between the content of the memory itself (Lafarge 1249). In her findings, Greenarce demonstrated the key role that screen memories could play in the reconstruction of both external and psychic reality. Screen memories according to Greenarce therefore promises access to the unconscious elements of the mind and can be used as a means to blend external reality and fantasy.

Moreover, through her tracing of evolution on screen memories, Greenacre illustrates how screen memory can serve (especially for the artist) as a valued creation and a frame in which new versions of the self and the imagined world can be developed (Lafarge 1254). Within Greenarce's findings of screen memories, Freud's theories present a new space for understanding memories, whereby fragments of the past present the potential 
for rediscovery as well as the possibility for the development of a new mnemonic practice found in the study of objects.

\subsection{Abjection and the Unconscious Mind}

Julia Kristeva's theory on abjection reflects the human reaction between subject and object or between self and other. In the opening pages of The Abjection of Horror, Kristeva writes:

"There loom, within abjection, one of those violent, dark revolts of being, directed a threat that seems to emanate from an exorbitant outside or inside ejected beyond the scope of the possible, the tolerable, the thinkable, it lies there quite close, but it cannot be assimilated. [...] Unflagging, like an inescapable boomerang, a vortex of summons and repulsion places one haunted by it literally besides himself. (1)

The understanding of "abject" as Kristeva puts it, "preserves what existed in the archaism of pre-objectal relationships, in the immemorial violence with which a body becomes separate in order to be" (10). As a result, Kristeva's theory provides this research with a secondary reading, placing the relationship between the female boy and the mannequin as seen in the narrative of Le Sommeil d'une mannequin, as an interpretation for the abject of self.

Kristeva identifies that abjection represents a revolt against that which gives our own existence or state of being. Drawing on the Jacque Lacan writing, we first experience abjection at the point of separation from our mother. Kristeva explains, that at this point, the child enters the symbolic realm, or law of the father, and as adults we confront the abject we simultaneously fear and identify with it. As a result, it sends us into a recalling state of being prior to signification where we feel a sense of helplessness. The self is 
threatened by something that is not part of us in terms of identity and non-identity, human and non-human. Kristeva writes that "the abject has only one quality of the object and that is begin opposed to I" (2). The theory of abjection articulates towards the ambiguous relationship found between an object and a subject. The state of abjection therefore is of particular interest because of its link between object and subject.

\subsection{Alternatives to Screen Memories: Benjamin and Baudrillard, The Art of Mechanical Reproduction and The Simulation of Reality Found in Film}

Walter Benjamin's “The Work of Art in the Age of Mechanical Reproduction" is a critical underpinning to the study of reproducible images found in film and art. One of the criticism to arise in Benjamin's thought is the use of film and its ability to displace, appropriate, and distort the "aura" of images. A major premise underlying the use of film, is that "it is a medium with a peculiar realist capacity to bring forth hidden or overlooked aspects of reality through its moving, and audiovisual recordings of appearance" (Ben-Shaul 3).

For a number of reasons, the work of Walter Benjamin is still discussed in current debates on cinema and new media. According to Benjamin, "the idea that a photograph is a copy of something in the 'real world' means that it can be interpreted as a form of vision that challenges the concept of authenticity by displacing the 'aura,' or uniqueness, of the original form. At the same time, as it is a copy of an original, photography still upholds the distinction between what is real and what is artifice. Whereas the authority of the original is undermined by mass reproduction, it nonetheless retains its status as an original in Benjamin's schema, although "the quality of its presence is always 
depreciated" (qtd. in Toffoletti 55). In other words, according to Benjamin, photography is a process of progressive emancipation or reproductive technology derived from the aura. Moreover, Benjamin explains how the mechanical means of production opened up a way of imitating an original through a copying process for the first time (Toffoletti 55).

The potential for infinite reproduction of an object by mechanical reproduction offers a democratizing corrective to what Benjamin decrees are the outmoded and elitist concepts of authenticity, essence, and aura associated with the myth of origins. For Benjamin, the aura is dead and exists only in an improbable and mystical space. The "aura" or authenticity lost through the reproduction of images that this research engages argues that the liberation of the aura in film is not necessarily contingent to the avant-garde movement of Surrealism, whereby the the concept of the aura tends to detach itself from this wider context. Benjamin's work in relation to film however, can be thoroughly explored in the writings of French theorist and filmmaker, Jean Epstein.

For Epstein, the 'photogenic' image was a revolution in cinematography. The concept of 'photogenic' implies the cine-camera's unique ability to reveal hidden dimensions of the photographed object (Ben- Shaul 1). Those hidden dimensions of reality for Epstein could be revealed through cinematic devices such as varying lenses, changing camera distance and angles, shifting the camera's recording speed from fast to slow motion, and editing rhythms (1). In sum, for Epstein, filmmakers should bring forth the elusive photogenic qualities of figured objects and people through all available cinematic devices. 
In “The Deepening of Apperception: On Walter Benjamin's Theory of Film” Rodolphe Gasché writes:

According to Benjamin, the technology of reproduction that leads to film via photography reflects and responds to profound social changes. More precisely, film and its technique of reproduction-as well as the hitherto hidden reality that it brings to light, helps us to come to grips with the new tasks that "the human apparatus of apperception" faces at a crucial "historical turning point," since these tasks "cannot be performed solely by optical means, that is, by way of contemplation [...] film allows for what Benjamin calls a deepening of apperception [...] Such deepening corresponds, or rather responds, to "profound changes in the perceptive apparatus-changes that are experienced on an individual level. (28-29)

Using this quotation as a point of departure, this research project subsequently draws on the writings of Baudrillard's "Simulacra and Simulation" in order to address questions about the improbable and "mystical space" brought forth by Benjamin. The simulation of spaces created by the apparatus of perception, introducing us to unconscious optics and impulses which film inevitably brings forth. The simulacra that Baudrillard refers to is one of signs and symbols found in contemporary media (i.e. film, television, photographs, etc.) and its perception of reality. Baudrillard's notion of the "simulacra" shatters the traditional distinction between the object as origin from the image it simulates. Moreover, Baudrillard claims that the simulated image (e.g. film) does not originate from something beyond it (such as reality) but proceeds to originate what it presents (Ben- Shaul 5). Thus, the concept of simulacrum implies that film is neither a reproduction of reality nor that of artistic abstraction. For Baudrillard, "reality is not an origin from an image re-presenting it since 'reality' is always-already and image or simulation" (5). 


\section{Chapter 4}

\section{Analysis, Discussion, Result}

Le Sommeil d'un mannequin uses film as a tool for remembering what is past, and serves as visual evidence for the engagement between the female body and that of the mannequin. In this respect, Le Sommeil d'un mannequin focuses on the projection and perception of memories found during the fabrication of the mannequin, during which film was used to extract, capture, and illustrate past memories that were found in the mind of the female participant. In this final section I explore the concept of "memory" in relation to filmmaking and explain how the medium of film was used as an externalized form of memory. Subsequently, I analyse how the relationship between the object of the mannequin and the female body speak to properties of the abject of self, proposed in The Powers of Horror: An Essay on Abjection, by Julia Kristeva. To conclude, my research engages in a discussion, combining the components of film making, the concept of memory and the practice of surrealism.

\subsection{Synopsis}

Produced with the aesthetic of surrealism, Le Sommeil d'un mannequin subsumes concepts of desire, anxiety, and fear, found in the recollection of memories. Le Sommeil d'un mannequin explores the transferring of human essence between a human and an object, as well as the transformative power of memories recalled during this exchange. Using relived experiences of reality to anchor content of fantasy, Le Sommeil d'un mannequin traces the events of the protagonist's memory in order to stimulate 
conversation about the construction and re-evoking of transferred memories that are present in the inanimate body of the mannequin.

\subsection{Analyzing the Narrative and Film Technique in Le Sommeil d'un mannequin}

The opening scene in Le Sommeil d'un mannequin functions as a frame for the film's narrative puzzle and foreshadows the development of the plot. The flashing images offer the audience fragments of memories rather than a continuous narrative. Taking the audience from a reality state to a dream one, this scene ends with overlapping images of the female protagonist suddenly being brought to a stop. The camera holds the frame and gazes into her eyes only momentarily before fading into a black transition, signaling an entrance into the dream world (Figure 7.).

As we enter the transitional dream world (00:52) the narrative unfolds and the film begins to reveal the subjectivity of the female protagonist. At the same time the narrative moves towards the transformative power of memories recalled during the transition of the female protagonist from human to mannequin. In between this scene, the audience experiences the interruption of superimposed images that creates a split between the protagonist and an essence that resides within her own body (Figure 8.). The visual narrative in this scene reflects a sense of human presence inherent during the final transition and construction of the mannequin.

The distinction between the female protagonist's subjectivity against the mannequin paradoxically comments on 'aura' that is absent within the mass-production of

mannequins. Even though mannequins have been made to resemble the human form, 
they are also limited by characteristics of the human entity. What is absent between the female body and that of the mannequin is the recognizable quality of human existence. Thus in the representation of the human aura, Le Sommeil d'un mannequin assumes this distinction and further uses characteristics of surrealist practice to overcome the limitations of human presence. A common visual trick of surrealism is the use of juxtaposition and superimpositions (Greenman, 28). The visual narrative in this scene, which creates a sense of an inhabiting human presence, employs a symbolic expression of human existence. This situation is further complicated by considering Freudian notions regarding the relationship between memory and film.

With the advent of psychoanalysis tied to the practice of surrealism the images in $L e$ Sommeil d'un mannequin also invites viewers into the absurdity of memories found within the depth of the unconsciousness. From the perspective of psychoanalytic studies, the preceding scene presents the experience of reality and the ensuring survival of the experiencing self onto the body of the mannequin. In "The Screen Memory and the Act of Remember", Lucy LaFarge states, "Through a split in the self, [one] captures a sense of the knowing [...] The sharp frame, which is often part of the screen memory, further secures a picture of the self as seen and known and serves as an enduring frame in which these images can be re-evoked" (1245). Moreover, as Greenacre's notes:

"a screen memory can be seen as a special kind of representation that is formed by an individual under strain and is held because it is felt to organize an experience that might potentially overwhelm the individual capacity to make sense of experience (and along with that his sense of a knowing, organizing self). Screen memories [...] are used to evoke a remembered experience and the self who registered that experience [...]" (qtd. in LaFarge 1254). 
Thus using the paradigms of screen memories this scene constructs a setting in which the perception of the mannequin attempts to create a meaningful pictorial experience, which can later be re-experienced as a recalled memory of the self. At the end of this scene the image of the female protagonist, who has transformed herself into a mannequin, slowly fades and during the last seconds the audience is forced to focus on her haunting disguise. At this time the female protagonist has matched her identification with the body of the mannequin.

In the next scene (02:37) we are shown a close-up of the mannequin's body that gradually fades into darkness (Figure 9.). The cinematic technique used exaggerates the contrast and exposure of lighting in order to further comment on the dream state. During the fade-in to the next scene the camera pans across the cracks and imperfections of the mannequin's body. The visual analogies of the mannequin and voiceover are concerned with the recalled memories found during the mannequin's construction. The inclusion of a narrated voiceover is meant to share the protagonist's observations during her transitional phase from human to mannequin. Furthermore, the inclusion of a voiceover allows the viewers to enter the inner thoughts and self awareness that is found in the protagonist's mind.

"When the object could be seen descending from the top, lights, a shadow was cast that only I could see.

The angle was ever so slight, the faintest brushing on the corner.

When the piece hit the ground, I could no longer see it. But it was still there. Merely trapped below" 
Entering into another transitional state $(02: 38)$ the scene begins to fade in and out of darkness, revealing a haunting recalling of eyes. The juxtaposition of the mannequin's body recalls an experience that the audience has already been introduced to in the opening scene. Formed by the juxtaposition of the mannequin's breast, the image on screen creates the illusion of eyes (Figure 10.). The illusion of eyes enables the audience to place the memory back to past events and recognize this scene as an act of remembering and repetition. It should also be noted that repetition in surrealist practice caters to the disruption of spatial coherence. Thus the use of repetition found in $L e$ Sommeil d'un mannequin speaks to the fortunes of surrealist practice.

A fade out carries us into the final scene (04:00). In this scene, the audience is invited to view a fully transformed mannequin (Figure 11.). However, as the camera slowly pans across the mannequin's face the scene is interrupted with another memory, entering the mind of the mannequin. The use of jump cuts between real and fantasy are made distinguishable between the image of the static mannequin and that of the moving one (Figure 12.-13.). The interchanging shots in the final scene suggest evidence of human essence found in the body of the mannequin. No longer an inanimate object, the mannequin, through the process of production, has created a new identity: one that is inherent in the psychic process of identification.

\subsection{The Abjection of the Mannequin: From Object to Abject}

The border between abject and subject according to Kristeva is imaginary. When we are propelled into the world of the abject, our imaginary borders disintegrate and the abject becomes a tangible threat because our identity system and conception of order has been 
disrupted (Pentony). Hence, because Kristeva's theory of abjection is concerned with figures that are in a state of transition or transformation, Le Sommeil d'une mannequin arguably eludes between both abject and subject. The state of abjection is of particular interest because of its link between psychoanalysis and the subconscious mind. In $L e$ Sommeil d'un mannequin, abjection is encountered by the protagonist as we enter her unconscious state. The impact of abject is reflected in the protagonists haunting disguise as she transforms into a mannequin. In this state the sensation of fear and horror (derived from the uncanny mirror of the protagonist body) are explicitly experienced as the protagonist experiences a loss between the self and other, as she is reminded of her body's own materiality.

\subsection{The Results of Using Film \& Memory Within a Surrealist Practice}

Methods of research-led practice moved this project towards an array of possibilities, both creative and academic. Using practice-led research allowed my project to undertake, by means of artistic practice, new directions in research and knowledge creation. Moreover, crossing methods from practice-led research with the study of material culture contributed to knowledge that used the medium of film as a visual form of engaging with meaning inherent in culture objects. The original goal of this research was to find new evidence that could describe the relationship between the mannequin and the female body. Instead, what emerged from the use of the described methodology and theoretical framework was a new visual knowledge of understandings regarding the female body in its replicated form. 
As a result, the speculations and interpretations that I observed during the process of building my mannequin were heavily rooted in Freudian concepts of memory and autobiographical construction alike. The process of building my mannequin uncovered unexpected meanings emerging from the object of the mannequin. Moreover, the result of my experimental film, worked towards the concept of autobiographical memories found in the conscious, and at times unconscious, mind. Thus, in keeping with the central premise of practice-led research, I conducted experimental and interpretive research from my speculation stage, and the result of my visual analogies led me to theorize my findings within psychoanalytic practice.

The use of film, the study of psychoanalysis, and the use of surrealist practice led this research in a significant exploration of memories -extrapolated from cultural objects. With film's ability to move through time and space, Le Sommeil d'un mannequin illustrates how powerful the use of this medium can be to convey and communicate the psychic experience of memory. Using film for this research project not only granted visual access to the unconscious mind, but by way of documenting and recording reality through experimental exploration, I was able to juxtapose imagery of memory through the use of film techniques.

The concept of "memory" is understood within the parameters of psychoanalysis to better engage with the projection of the protagonist's consciousness versus her unconsciousness. Le Sommeil d'un mannequin lays the groundwork for exploring memory as both voluntary and involuntary, and it illustrates how the mannequin seeks to reconstruct and resurrect a relationship between memory and the female body. 


\subsection{A Discussion of Prown, Freud, Benjamin and Baudrillard}

Scholars like Jules Prown and Igor Kopytoff suggest that we study cultural objects in order to understand the collective memory of a given society. Collective memories, one might argue, often has ties to political and societal dimensions. In other words, collective memories are constituted in part by social and political patterns, and as a result, have had an effect on our personal and or public memory. However, Jeffrey K. Olick from Columbia University refers to collective memories in his essay, "Collective Memory: The Two Cultures", as something that is twofold. He argues that collective memories can also be opened to "psychological considerations, including neurological and cognitive factors [...]". Considering the "psychological and neurological" factors involved in understanding collective memories, this research therefore approaches the concept of collective memories with a psychoanalytic lens. Thus applying Freudian insights to my research has helped to theorize the unconscious dimensions of memory.

The concept of screen memories found in Freud's writing led to an unexpected relationship between film, memories, and the mannequin. The use of screen memories in Le Sommeil d'un mannequin was used as a temporary displacement in which the forgotten memory was subject to recall reality. Drawing on Freud's work, this research has come to understand the displacements of memory as "displacement as well as replacement of memory, disembedding as well as reembedding" (Freeman 2).

Le Sommeil d'un mannequin represents screen memories in the act of remembering and the content of what is remembered in order to evoke the experience of the constructing self. Thinking particularly with regard to the self, Le Sommeil d'un mannequin goes back 
and forth between internalized perspectives, and the view of the experienced self that was brought forth by the camera also explores the abject of self. The sharp frame of the mannequin further secures a picture of the self as seen and as known.

Although Baudrillard's concept of the industrial simulacrum reflects a duality with Benjamin's writings on reproduction, Baudrillard's thinking diverges considerably from Benjamin's in his formulation of a third order of the image where the very notion of a real and its artificial reproduction collide and implode. This research used Baudrillard's theories about the image to question how reality is experienced and understood within the context of filmmaking and it relation to the camera apparatus. This research acknowledges Baudrillard's theory, whereby Le Sommeil d'un mannequin challenges our perception of reality in so that the moving images in Le Sommeil d'un mannequin are neither real nor imaginary but rather simulations of the unconscious mind. 


\section{Conclusion}

This research project sought to illuminate the relationship between the body of the mannequin and the female body. Although mannequins have been made to take on the human form there are certain human characteristics that cannot be replicated, in particular, human essence or presence. While mannequins may look like us, stand tall like us, even pose like us, they are not us. Paradoxically, however, even though mannequins may not think or feel, within the discourse of material culture, the body of the mannequins speak to a cultural history, collective memory, and subjective experience. This project engaged with the mannequin as a culture object that bares an autobiographical past. The mannequin is brought to life through film and the relationship between the human body and the body of the mannequin is examined through psychoanalysis and concepts of screen memories. This project, to end, recontextualizes the body of the mannequin, and the female body, as capable of encountering ideas aside from phallic anxiety. Le Sommeil d'un mannequin celebrates the engagement to feminist filmmaking and feminist surrealistic practice and speaks to an alternative voice. 


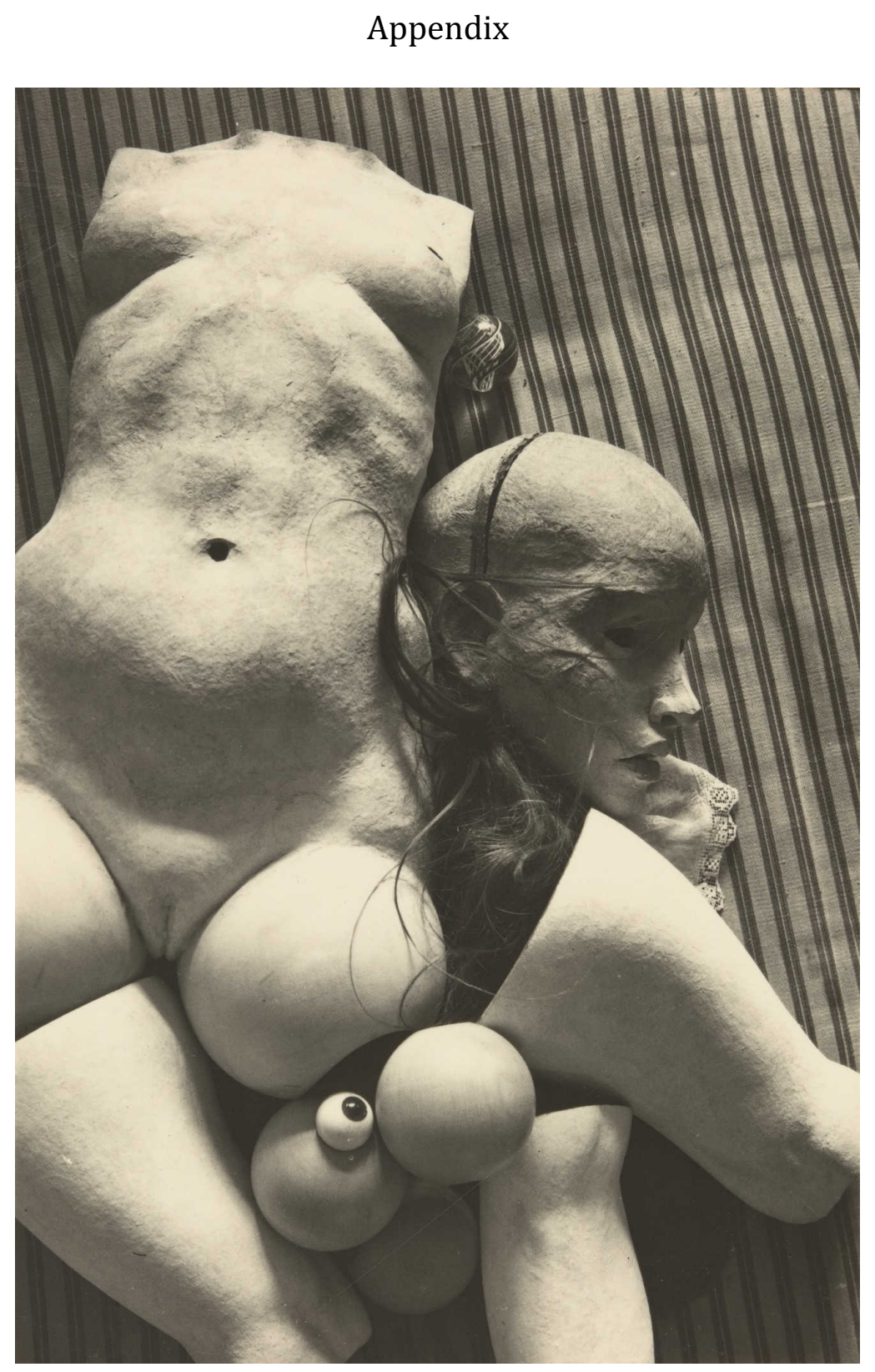

Figure 1. Hans Bellmer, Plate from la Poupée, 1936.Gelatin Silver Print. Museum of Modern Art, New York. 


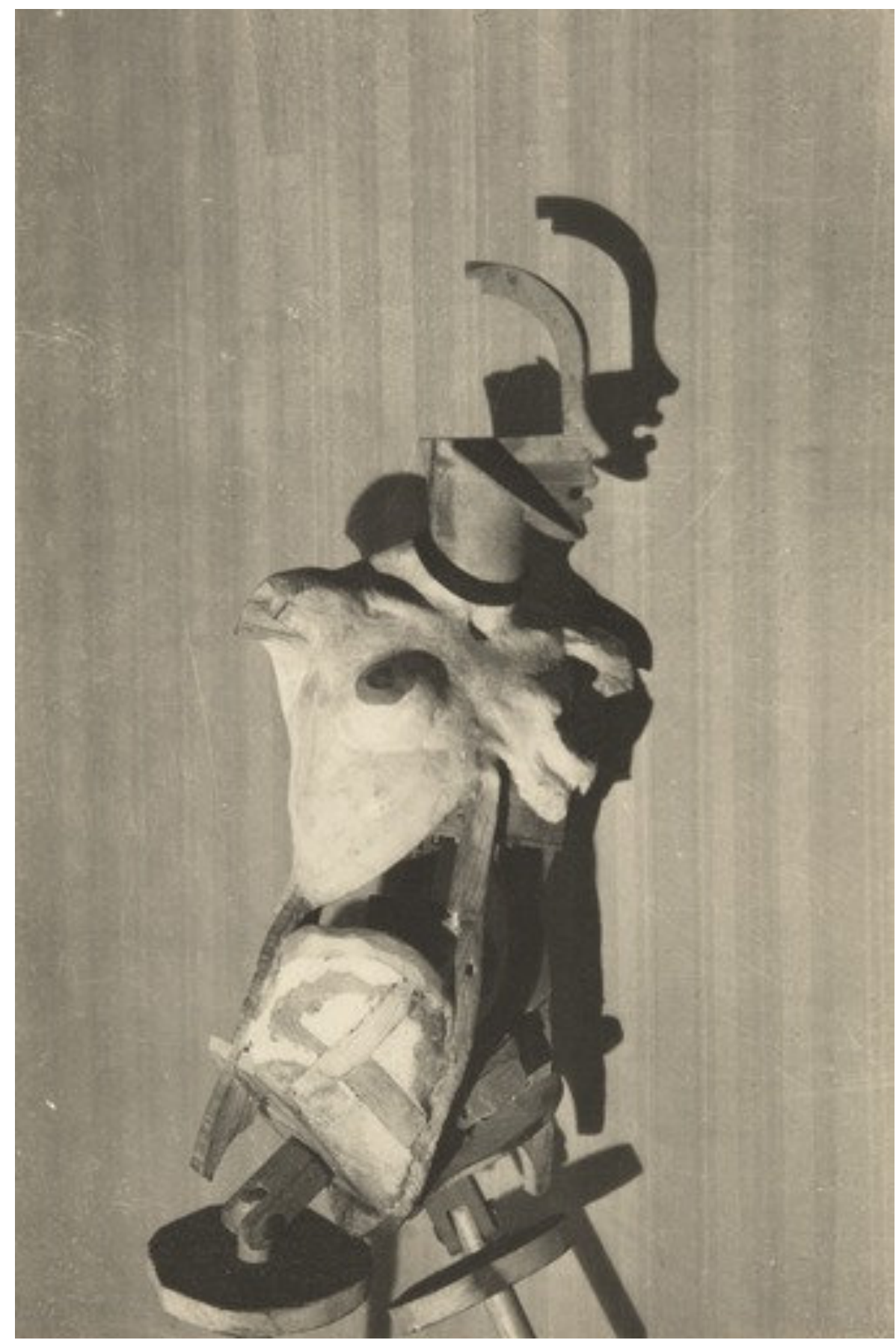

Figure 2. Hans Bellmer, Plate from la Poupée, 1936.Gelatin Silver Print. Museum of Modern Art, New York. 


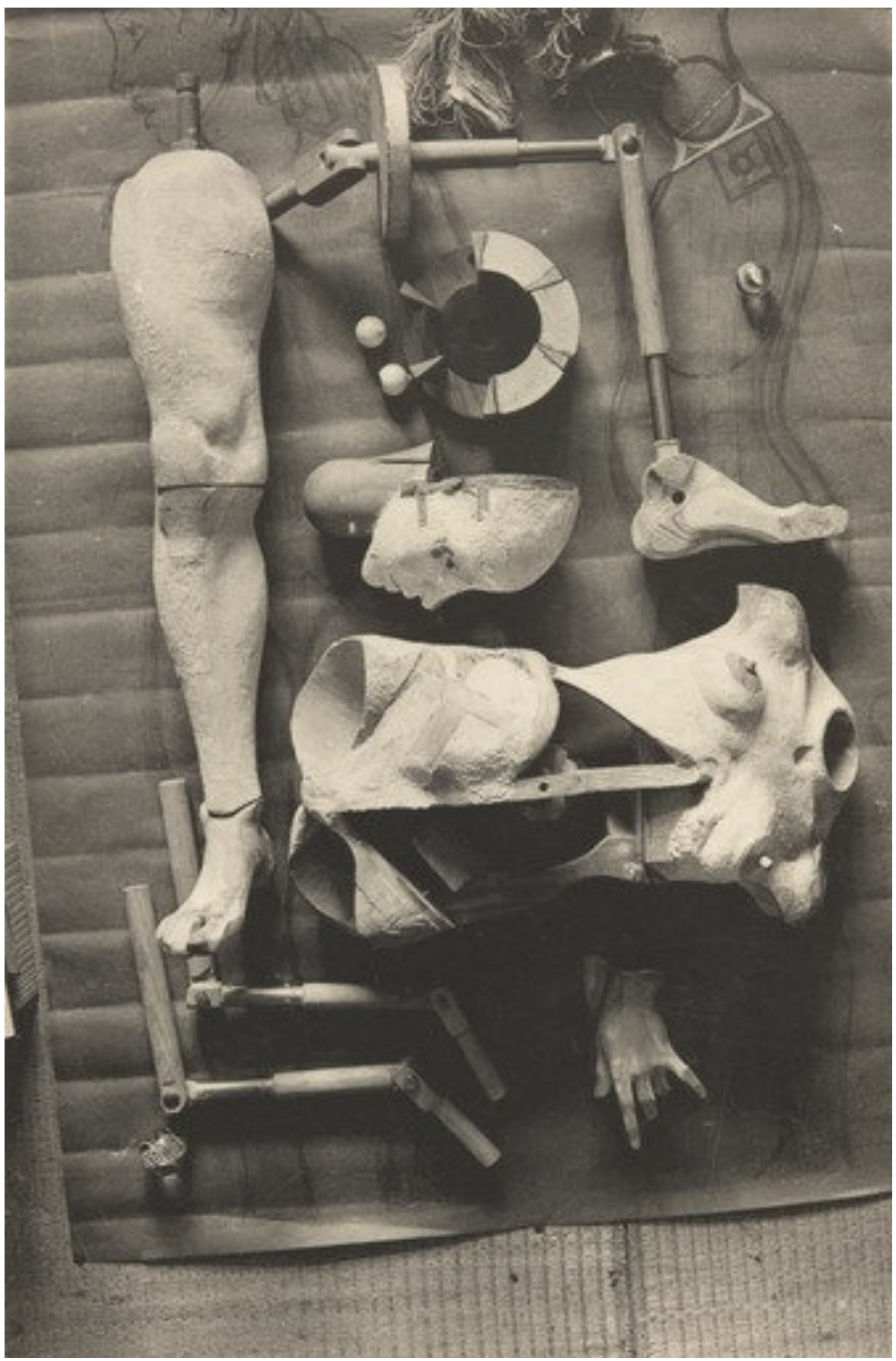

Figure 3. Hans Bellmer, Plate from la Poupée, 1936.Gelatin Silver Print. Museum of Modern Art, New York. 


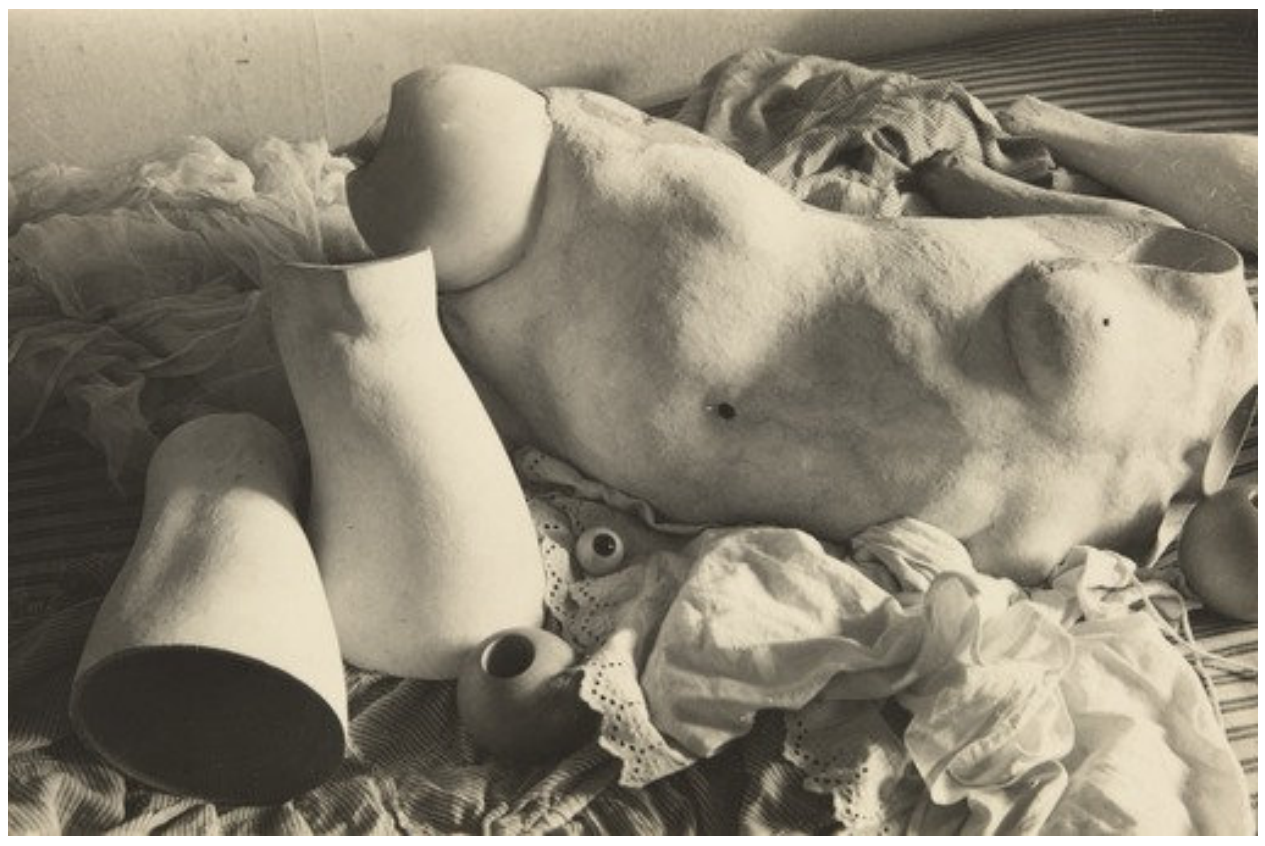

Figure 4. Hans Bellmer, Plate from la Poupée, 1936.Gelatin Silver Print. Museum of Modern Art, New York.

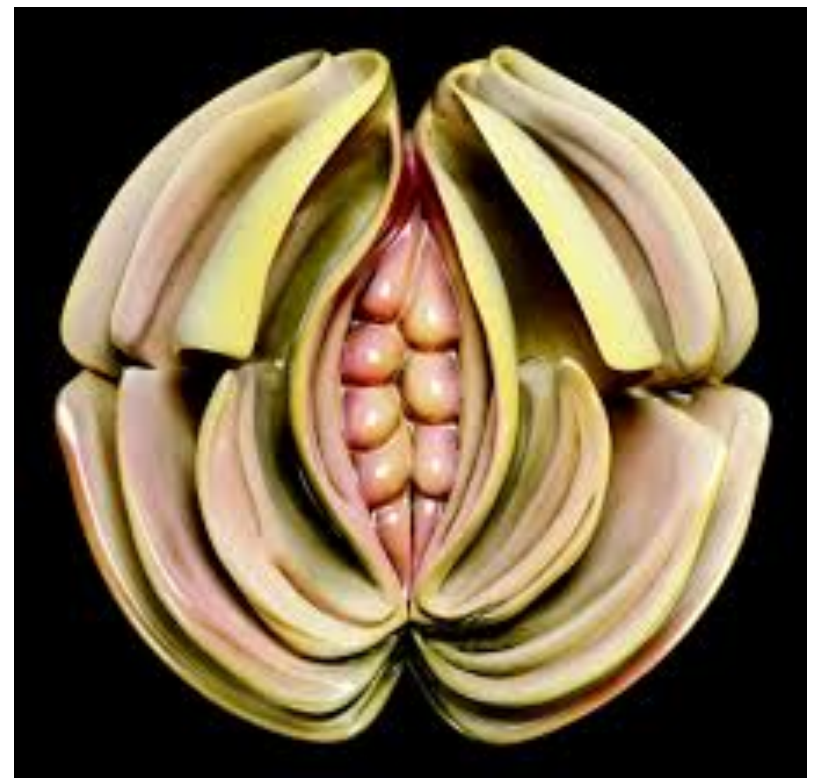

Figure 5. Judy Chigo. The Dinner Party (Virginia Woolf Place Setting).1974-79. Mixed media: ceramic, porcelain, textile. Brooklyn Museum, New York. 


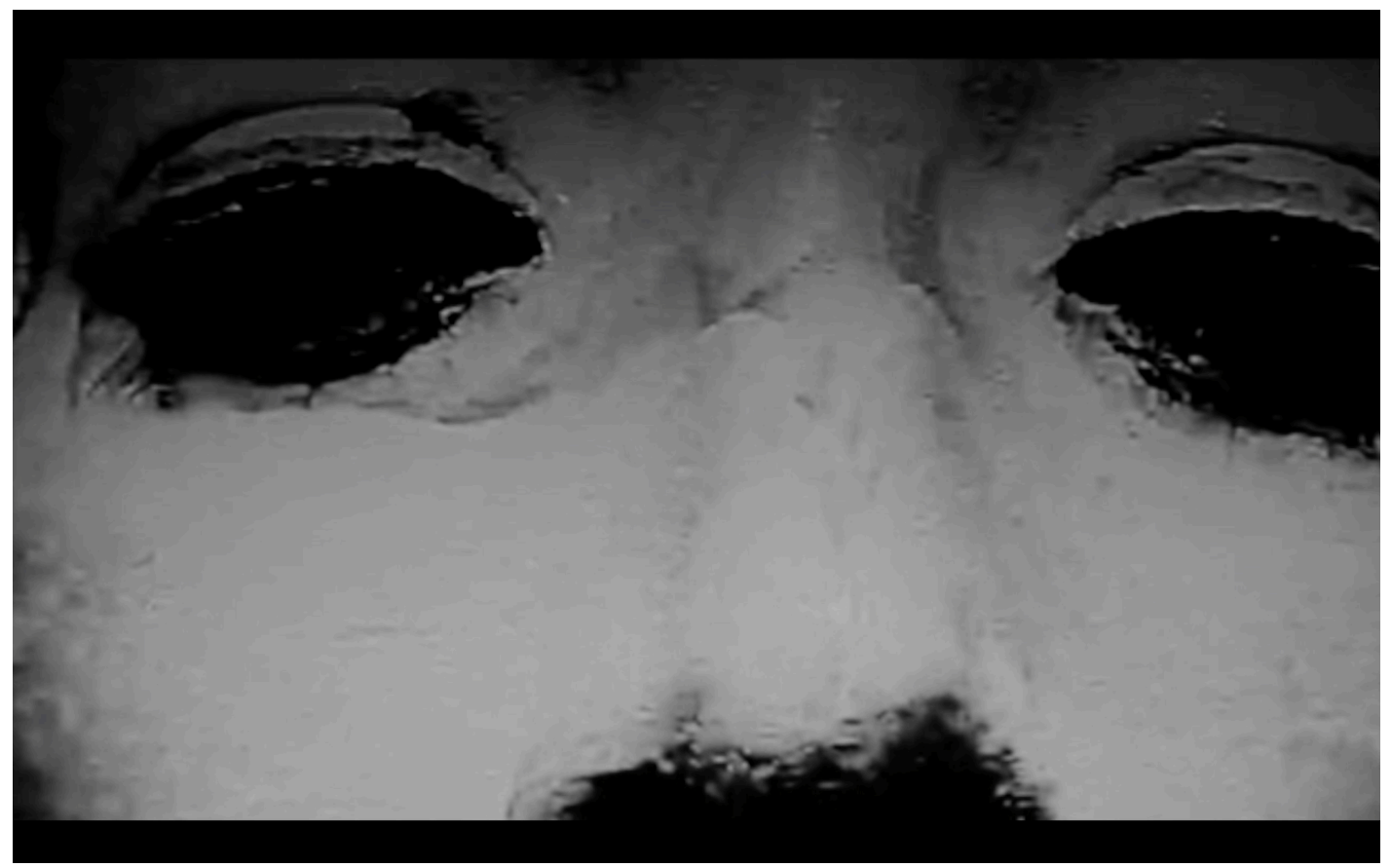

Figure 6. Le Sommeil D’un Mannequin. Dir. Laura Del Giacco. Perf. Marianna Del Giacco. 2016. Film

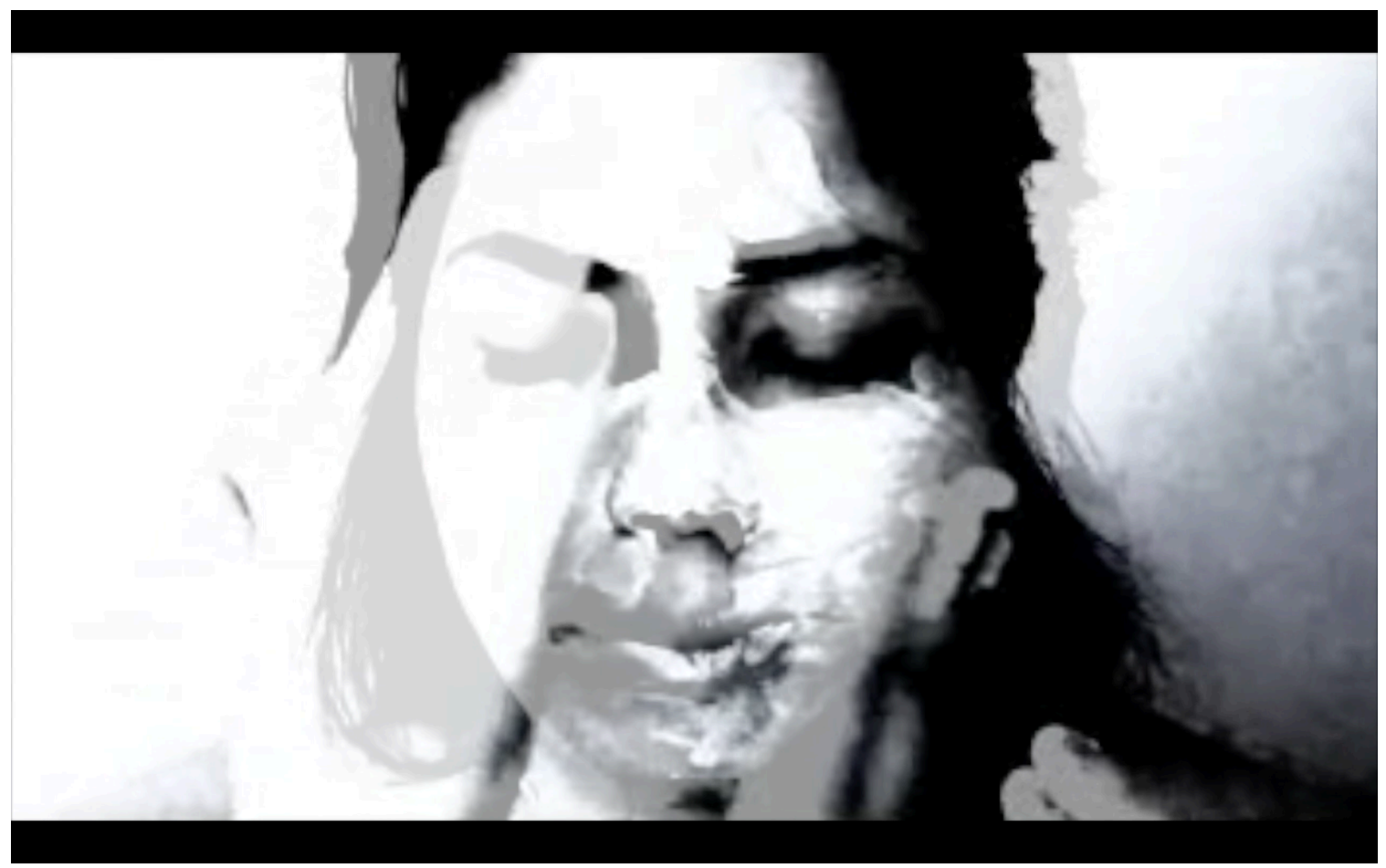

Figure 7.

Le Sommeil D’un Mannequin. Dir. Laura Del Giacco. Perf. Marianna Del Giacco. 2016. Film 


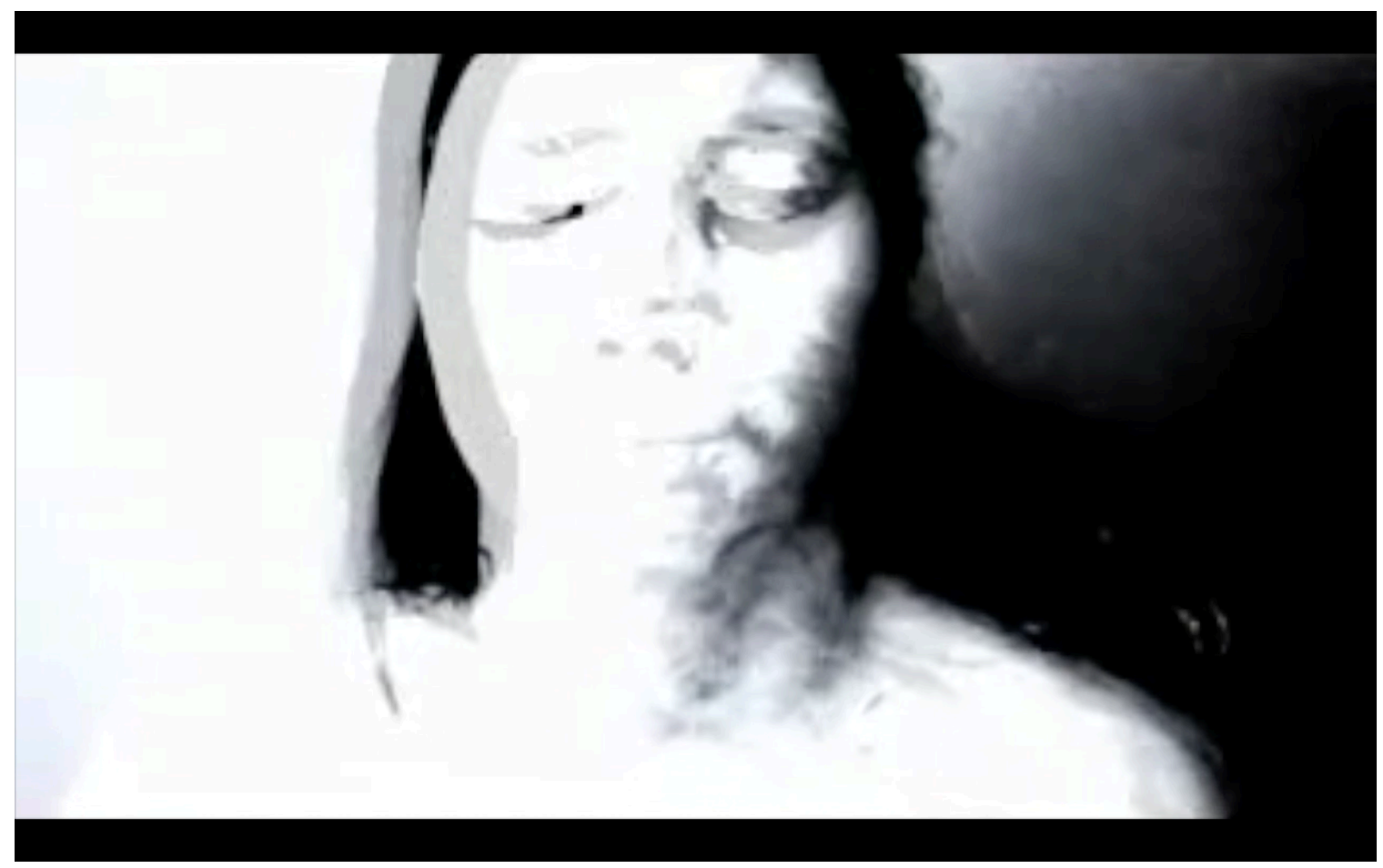

Figure 8. Le Sommeil D’un Mannequin. Dir. Laura Del Giacco. Perf. Marianna Del Giacco. 2016. Film

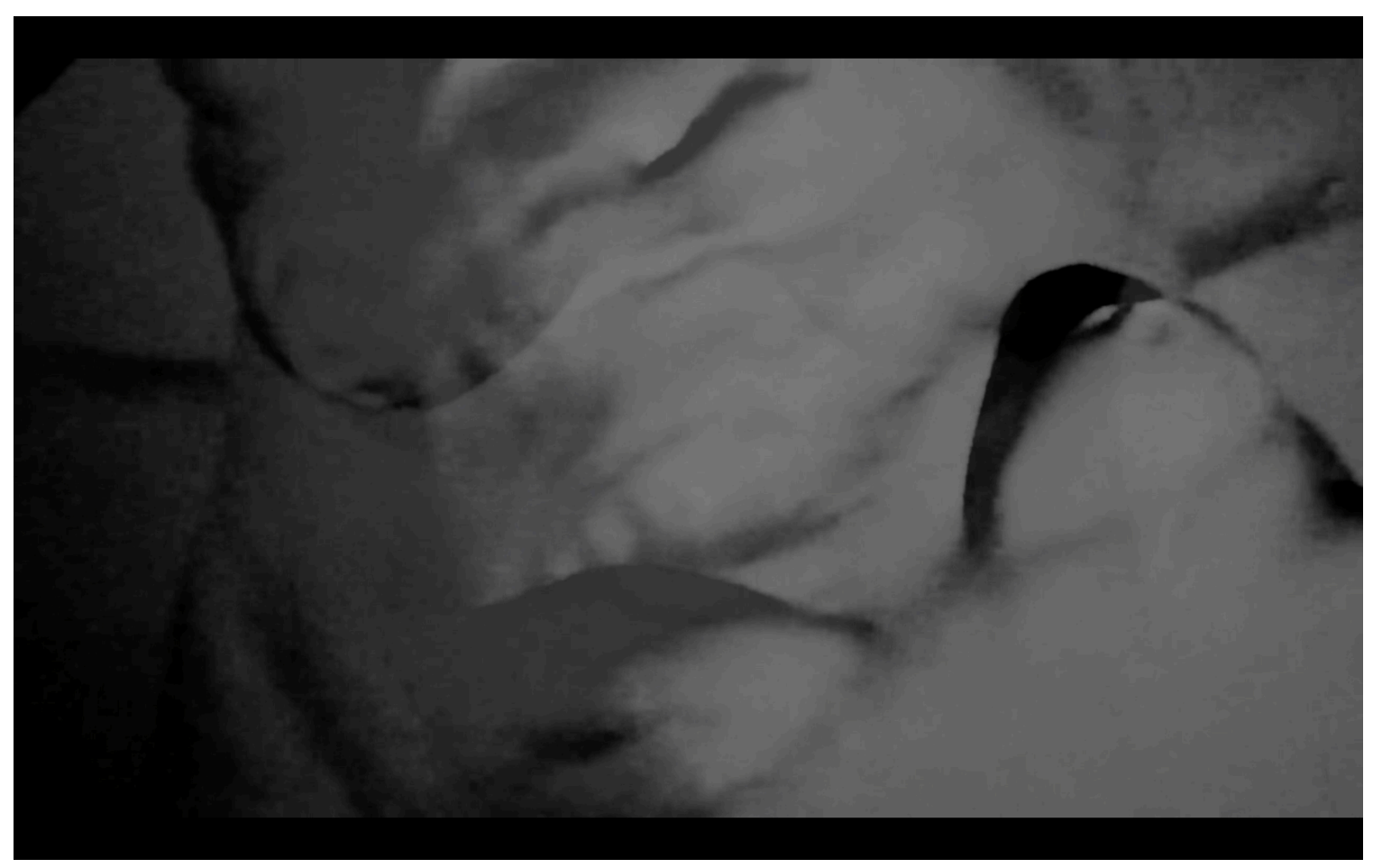

Figure 9. Le Sommeil D’un Mannequin. Dir. Laura Del Giacco. Perf. Marianna Del Giacco. 2016. Film 


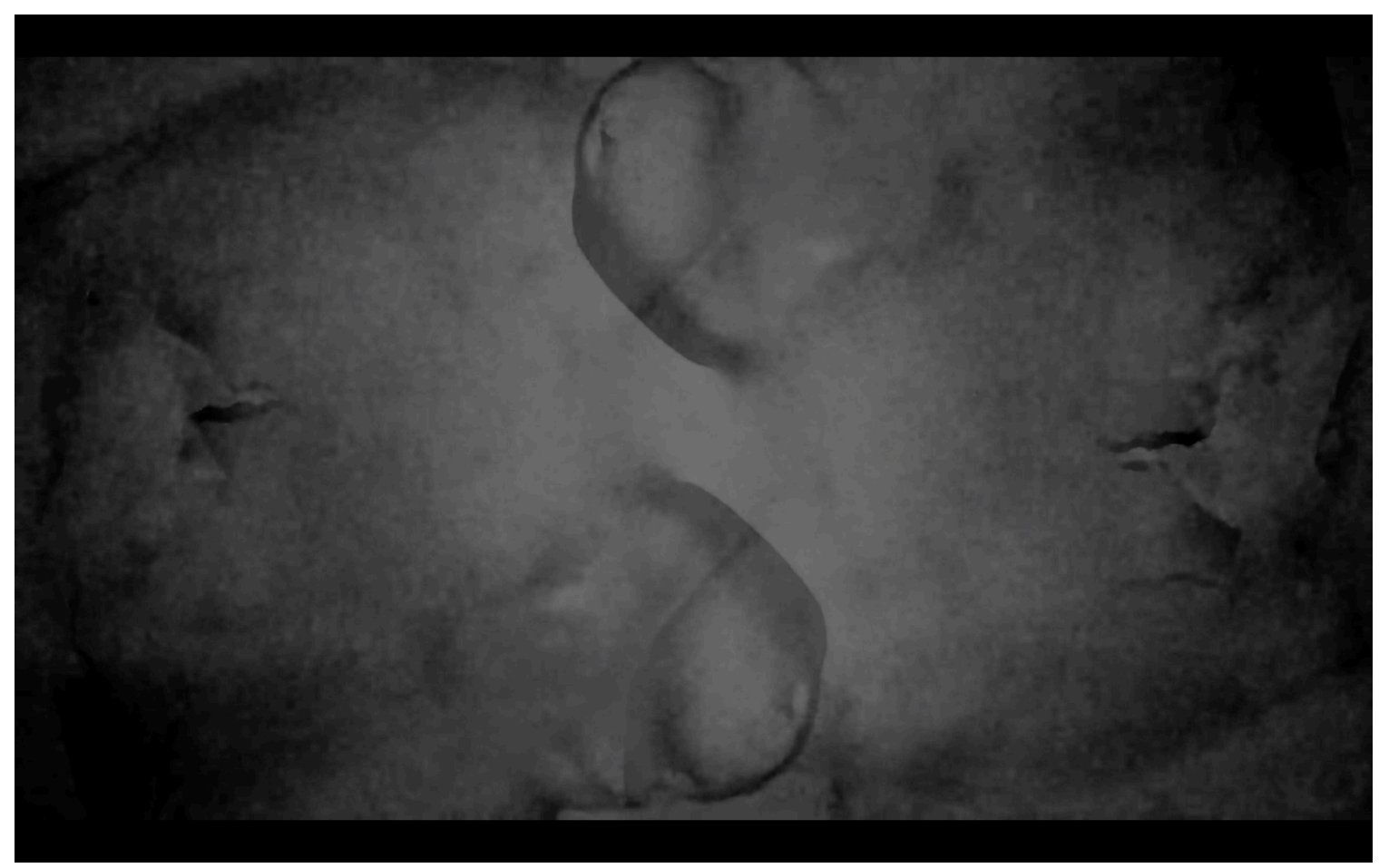

Figure 10. Le Sommeil D’un Mannequin. Dir. Laura Del Giacco. Perf. Marianna Del Giacco. 2016. Film

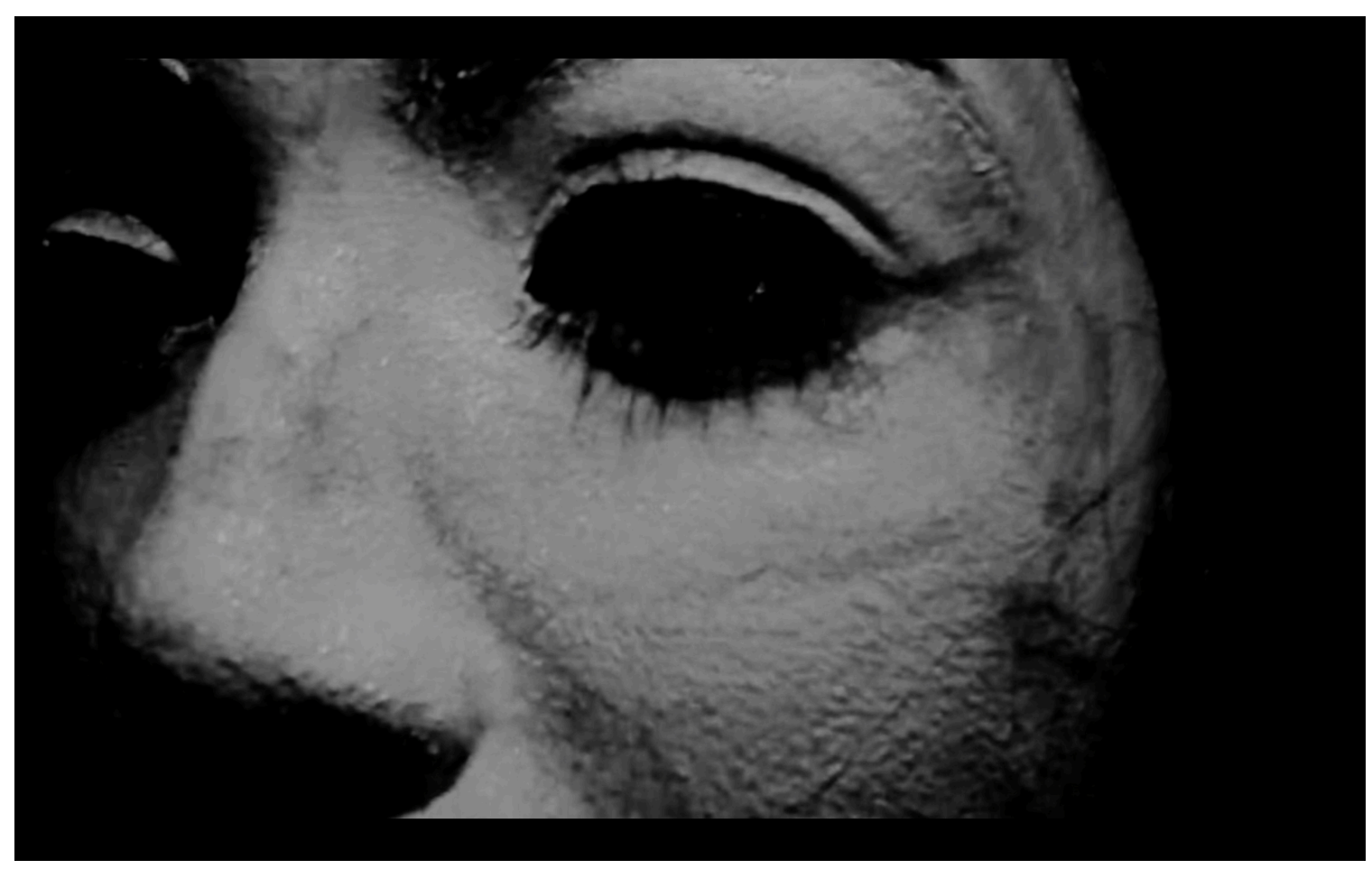

Figure 11. Le Sommeil D’un Mannequin. Dir. Laura Del Giacco. Perf. Marianna Del Giacco. 2016. Film 


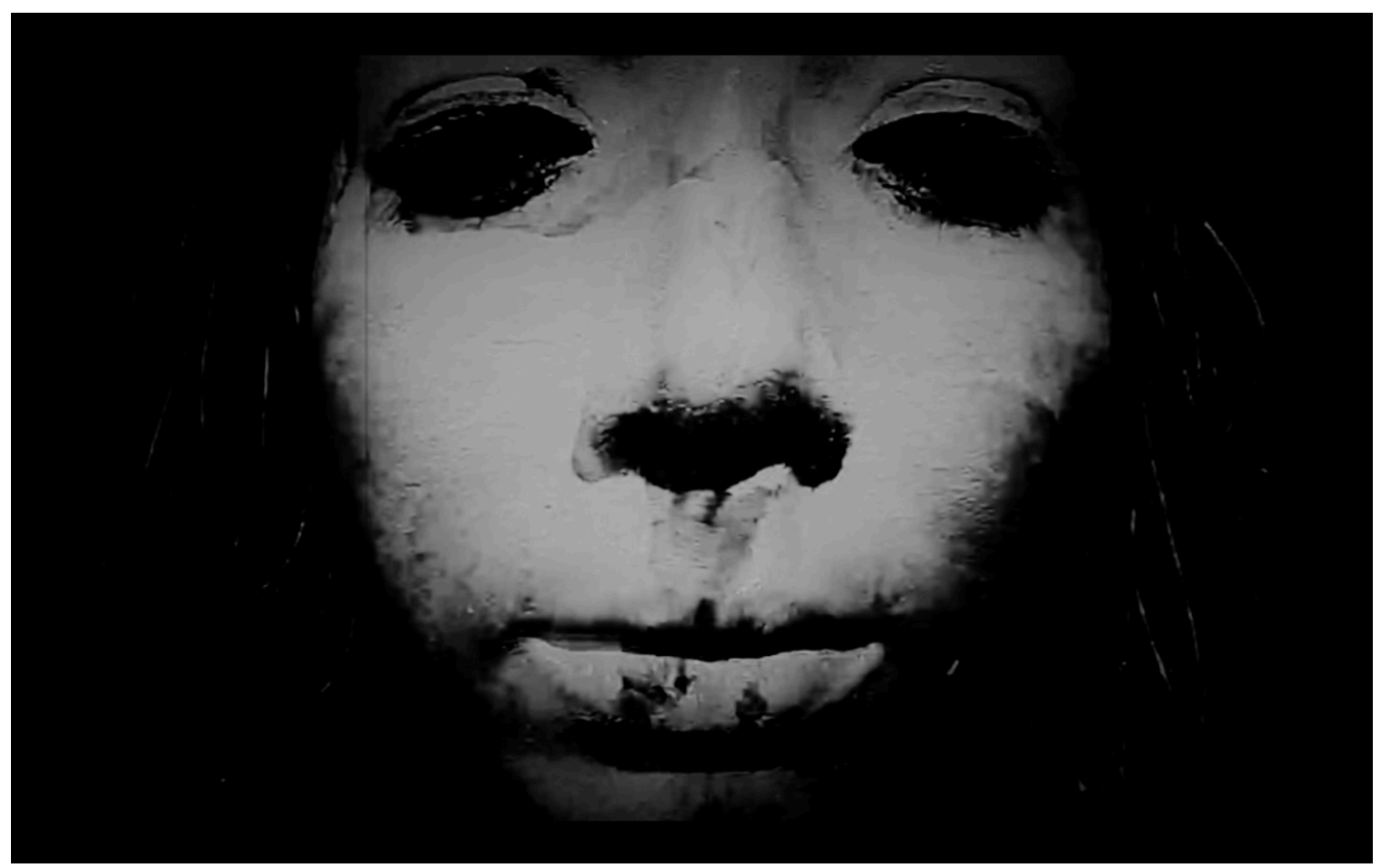

Figure 12. Le Sommeil D’un Mannequin. Dir. Laura Del Giacco. Perf. Marianna Del Giacco. 2016. Film

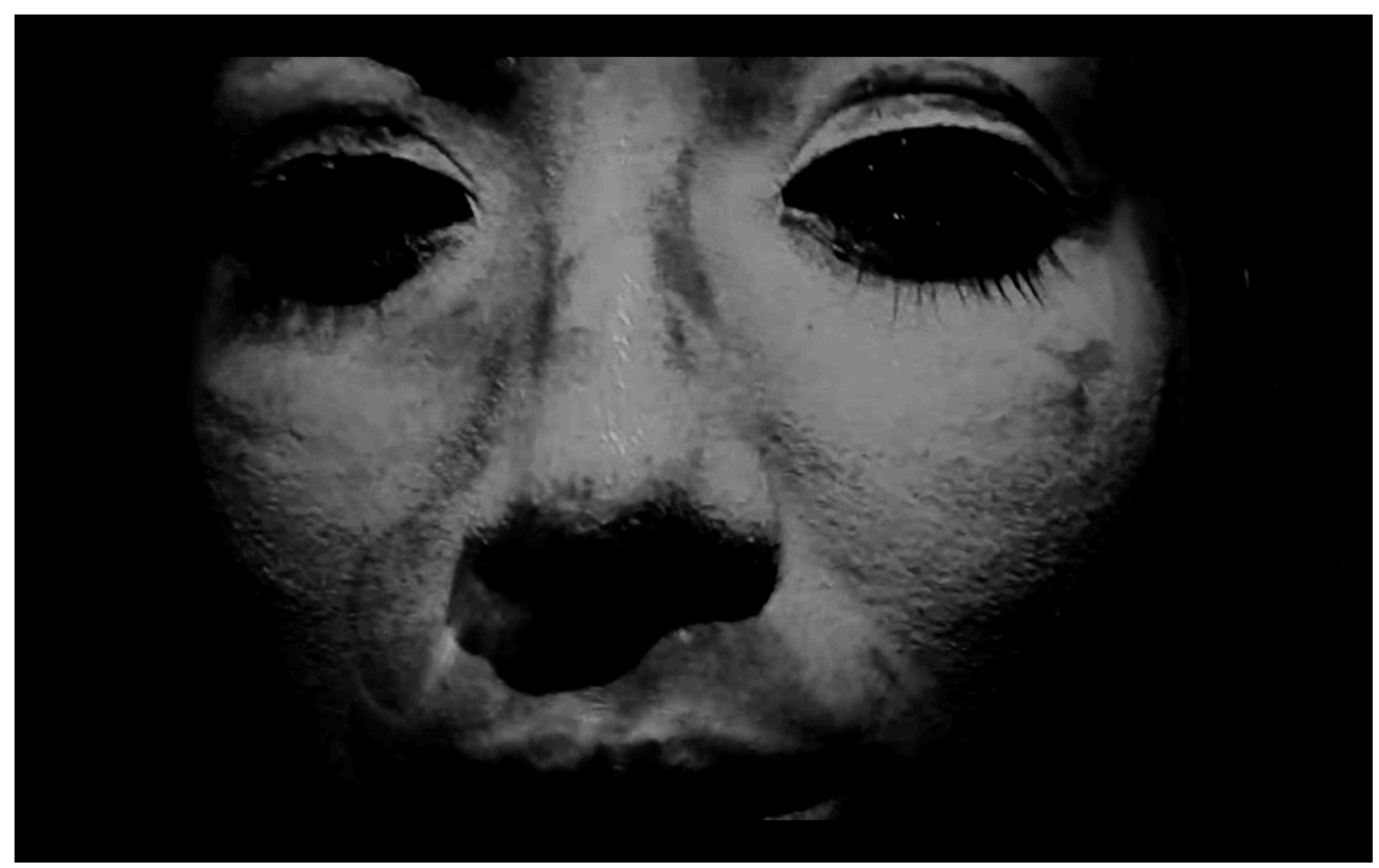

Figure 13. Le Sommeil D’un Mannequin. Dir. Laura Del Giacco. Perf. Marianna Del Giacco. 2016. Film 


\section{Works Cited}

Arnold Rebecca. "The Brutalize Body”. Fashion Theory. 3.4 (1999): 487-502. Web. Accessed. 15 June. 2015

Bancroft, Alison. Fashion and Psychoanalysis. London; New York: I.B Tauris \& Co Ltd, 2012. Print.

Baudrillard, Jean. Simulacra and Simulations. University of Michigan Press, 1994. Print

Benjamin, Walters. "The Work of Art in the Age of Mechanical Reproduction". Modern Art and Modernism: A Critical Anthology. Ed. Frascina, Francis and Charles Harrison. London: Sage, 1982.Print

Berger, John. "The Female Nude in Western Art". Ways of Seeing. London: BBC \& Penguin, 1972. 45-63. Print.

Biggs Michael, Henrik Karlsson. The Routledge Companion to Research in the Arts. London; New York: Routledge, 2011. Print.

Breton, Andre. Manifestoes of Surrealism. University of Michigan Press, 1969. Print

Calefato, Patrizia. The Clothes Body. Oxford; New York: Berg. 2004. Print

Crary Jonathan. "Modernizing Vision”. Viewing Positions: Ways of Seeing Film. Ed.

David Matthews, Alison. "Body Doubles: The Origins of the Fashion Mannequin". (forthcoming). The Journal of Design Dress.

Linda Williams. New Brunswick: Rutgers University Press, 1997. 23-34. Print

Conley, Katherine. "Surrealism's Ghostly Automatic Body". Contemporary French and Francophone Studies. 15.3 (2011)" 297-304. Web. Accessed. 15 June. 2015

Conor, Liz. The Spectacular Modern Woman: Feminine Visibility in the 1920's. Indianapolis: Indian University Press, 2004. Print.

Edelkoort, Lidewjii. Fetishism in Fashion. Amsterdam: Frame Publisher, 2013.Print.

Elliot, Andrews. Psychoanalytic Theory. London: Macmillan Publishers Limited. 2015. Print

Evans, Caroline. The Mechanical Smile. New Haven: Yale University Press. 2013. Print. 
Evans, Caroline. "Masks, Mirrors, and Mannequins: Elsa Schiaparelli and the Decentered Subject”. Fashion Theory.3.1 (1999):3-32. Web. Accessed 24 May. 2015

Evans, Caroline. "The Enchanted Spectacle”. Fashion Theory. 5.3 (2001):271-310. Web. Accessed 24 May.2015

Evans. Caroline \& Christopher Breward. Fashion and Modernity. Oxford; New York: Berg. 2005. Print.

Freeman, A. Lindsey, Benjamin Nienass and Laliv Melamed. "Screen Memory". International Journal of Politics, Culture, and Society. 26.1 (2013): 1-7. Web. Accessed 10 Feb. 2016

Gonberg, Tag. "Beware Beautiful Women: The 1920's Shop Window Mannequin and a Physiognomy of Effacement". Art History. 20.3 (1997): 375-396. Web. Accessed 20 January. 2016

Johnston, Claire. "Women's Cinema as Counter-Cinema”. Auteurs and Authorship: A Film Reader. Ed. Barry Keith Grant. Oxford: Blackwell Publishing, 2008. 110-118 Print.

Hoving. A. Kirsten. "Man Ray's Disarming Venuses: Deconstructing the Classical Torso in Surrealist Photography". History of Photography. 29.2(2005): 124-134. Web. Accessed. 15 June. 2015

Ju, Siel. "Simulations/Shape-Shifting Surrealism: Rikki Ducornet's Poetry of Feminist Intersubjectivity". Diss. College of Letters, Arts, and Science, 2008. Print.

Khan, Nathalie. "The Cutting of the Body: Why the Fashion Image is no Longer Still". Fashion Theory. 16.2(2012): 235-250. Web. Accessed 12 Mar. 2015

Knafo, Danielle. "What Does a Man Want? Reflection on "Surrealism: Desire Unbound"”. Studies in Gender and Sexuality. 4.3(2003): 287-307.Web. Accessed 18 June. 2015

Kopytoff, Igor. "The Cultural Biography of Things: Commoditization as Process". The Social Life of Things: Commodities in Cultural Perspective. Ed. Arjun Appadurai. UK: Cambridge University Press. 1986. 64-94. Print.

Kristeva, Julia. Powers of Horror: An Essay on Abjection. New York: Columbia University Press, 1982. Print

Kuhn, Annette. "A Journey through Memory". Memory and Methodology. Ed. S. Radstone. London: Berg Publication.2000. Print 
Kwan, Sara Chong, Morna Laing and Mario J. Roman. "Fashion and Memory". Critical Studies in Fashion \& Beauty. 5.2 (2014): 201-204. Web. Accessed 10 Feb. 2016

Laan Ellen, Walter Everaerd. "Habituation of Female Sexual Arousal to Slide and Film". Archives of Sexual Behavior. 24.5 (1995): 517-541. Web. Accessed 10 Feb. 2016

LaFarge, Lucy. "The Screen Memory and the Act of Remembering". The International Journal of Psychoanalysis. 93(2012): 1249-1265. Web. Accessed 10 Feb. 2016

Lemonnier, Pierre. "The Study of Material Culture Today: Toward an Anthropology of Technical Systems". Journal od Anthropological Archaeology. 5(1986): 147-186. Web. Accessed 28 March. 2016.

Levy, Helen. "Clothes Make the Mannequin: Covering Up the Female Body in "The Sheltered Life"'. Mississippi Quarterly. 49.2(1996): 255-267. Web. Accessed 10 February.2016

Lippard, R. Lucy. "The Pains and Pleasures of Rebirth: Women's Body". Art in America. 100.11(2012):99-116. Web. Accessed 10 February. 2016

Martin, Angela. "Refocusing Authorship in Women's Filmmaking". Auteurs and Authorship: A Film Reader. Ed. Barry Keith Grant. Oxford: Blackwell Publishing, 2008. 119-127. Print.

Metz, Christian. The Imaginary Signifier: Psychoanalysis and the Cinema. Indianapolis: Indiana University Press, 1982. Print

McRobbie, Angela. "Young Women and Consumer Culture". Cultural Studies.22.5 (2008): 531-550. Web. Accessed 11. May. 2015

Mitchell, Juliet. Psychoanalysis and Feminism. London: Allen Lane, 1974. Print.

Mulvey, Laura. Fetishism and Curiosity. Indianapolis: Indian University Press, 1996. Print.

Mulvey Laura. "Visual Pleasure and Narrative Cinema". Screen16.3 (1975): 6-18. Web. Accessed 12 Mar.2015

Nicholas, Bill. Engaging Cinema: An Introduction to Film Studies. New York; London: Norton \& Company Inc., 2010. Print.

Olick, K. Jeffrey. “Collective Memory: The Two Cultures". Sociological Theory 17:3 (1999): 333-349. Web. Accessed 2 April. 2016 
Petkova I. Valeria, H. Henrik Ehrsson. "If I Were You: Perceptual Illusion of Body Swapping”. PLoS ONE. 3 .12 (2008): 1-9. Web Accessed 10 Feb. 2016

Russell, Catherine. "New Media and Film History: Walter Benjamin and the Awakening of Cinema". Cinema Journal 43.3(2004): 81-84. Web. Accessed March 28. 2016.

Sandberg B. Mark. Living Pictures, Missing Person: Mannequins, Museums, And Modernity. New Jersey: Princeton University Press, 2003. Print.

Schneider, K. Sara. "Body Design, Variable Realism: The Case of Female Fashion Mannequins”. Design Issue 13.3(1997): 5-18. Web. Accessed 15 January. 2016

Sherwin, Miranda. "Deconstructing the Male Gaze”. Journal of Popular Film and Television. (2008): 174-182. Web. Accessed 10 Feb. 2016

Slater, Alison. "Wearing in memory: Materiality and Oral Histories of Dress". Critical Studies in Fashion \& Beauty. 5.1(2014): 125-139. Web. Accessed 10 Feb. 2016

Smelik, Anneke Pam. "Feminist Film Theory". The Cinema Book. Ed. Pam Cook and Mieke Bernink. London: BFI, 1999. 493-585. Print

Smith, Hazel, Roger T. Dean. Practice-Led Research, Research-Led Practice in the Creative Arts. London: Edinburgh University Press, 2009. Print.

Sullivan, Graeme. Art Practice as Research: Inquiry in the Visual Arts. Pennsylvania: Sage Publication. 2009. Print.

Timbs, John. Stories of Inventors and Discoverers in Science and the Useful Arts. London: Harper\& Brothers, 1860. Print

Toffoletti, Kim. Cyborgs and Barbie Dolls, Feminism, Popular Culture and The Posthuman Body. London: I.B.Tauris \&Co Ltd.,2007.Print.

Tredell, Nicolas. Cinema of the Minds: A Critical History of Film Theory. UK; USA: Icon Books \&Totem Books, 2002. Print.

Tythacott, Louise. Surrealism and the Exotic. London; New York: Routledge. 2003.Print

Uhlirova, Marketa. " 00 Years of the Fashion Film: Frameworks and Histories”. Fashion Theory. 17.2 (2013): 137-158. Web. Accessed.15 June. 2015

Wood, Ghislaine. The Surreal Body: Fetish and Fashion. London: V\&A Publication, 2007.Print. 
Ways of Seeing. Dir. Mike Dibb. Perf. John Berger. BBC, 1972. 